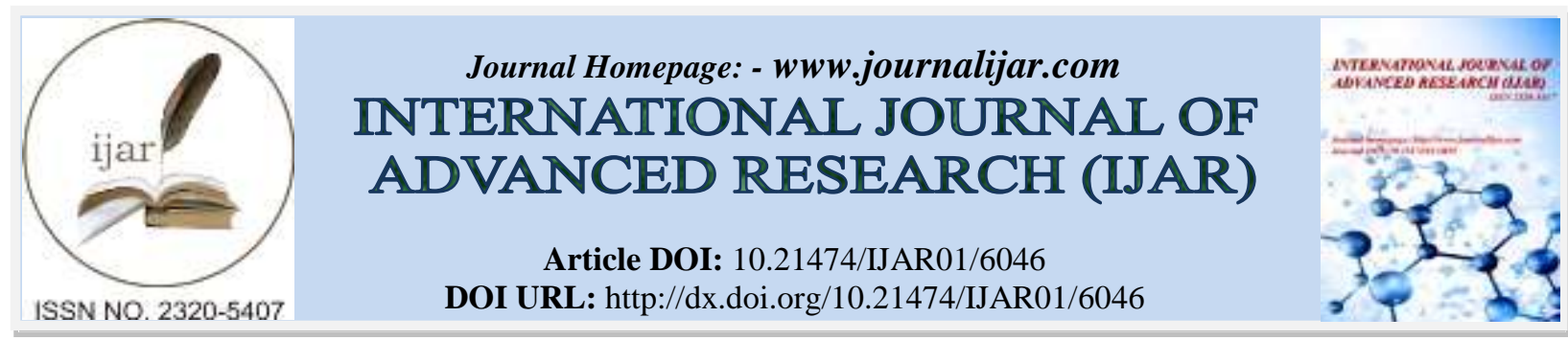

RESEARCH ARTICLE

\title{
ANALYSIS OF MAIN QUALITY CHARACTERISTICS OF PERSIMMON (DIOSPYROS KAKI L.) FRUITS.
}

\section{Muna Ahmed Mohamed El Hadi ${ }^{1,3}$, Qingzhong Bu ${ }^{1}$, Boxue Ge ${ }^{1}$, Chao Cao ${ }^{1}$ and ${ }^{*}$ Chunhua Zhou ${ }^{1,2}$.}

1. College of Horticulture and Plant Protection, Yangzhou University, Yangzhou, China.

2. Joint International Research Laboratory of Agriculture \& Agri-Product Safety, Yangzhou University, Yangzhou, China.

3. University of Gezira, Wad Medani P.O. Box 20, Sudan.

\section{Manuscript Info}

Manuscript History

Received: 13 October 2017

Final Accepted: 15 November 2017

Published: December 2017

Key words:-

Diospyros kaki, fruit quality, color, postharvest treatment.

\section{Abstract}

Persimmon (Diospyros kaki L.) is an important commercial and deciduous fruit tree with lots of cultivars. It is grown in various countries and is increasingly appreciated for its nutritional value, health benefits and rich flavor. In this research, persimmon fruits were used as plant materials to evaluate the main fruit quality characteristics of 34 different cultivars and to study the effect of ethylene and salicylic acid (SA) in main quality characteristic of two persimmon cultivars, namely 'Xiaofangshi' and 'Naiyoushi', during different ripening stages.

The average weight of fruit of non-astringent persimmon cultivars was heavier compared to astringent persimmon, while the differences in fruit shapes index among all the astringent persimmon cultivars was larger than that of non-astringent persimmon cultivars. Moreover, the average total soluble solids of the astringent persimmon cultivars was higher than that of the non-astringent persimmons, while titratable acidity was basically consistent in both non-astringent and astringent persimmon cultivars. On the other hand, results showed that there were no significant differences in main fruit quality including fruit weight, diameter and fruit shape index in two different cultivars during different ripening stages. While, both fruit firmness and total soluble solids showed significant differences in both two cultivars, results revealed that fruit treated with ethylene had the lowest firmness and the highest total soluble solids followed by control fruits, while fruit treated with SA had the highest firmness and the lowest total soluble solids. A comparison of fruit color between different persimmon cultivars showed that both the pulp and the peel of astringent persimmon had deeper orange red color compared to non-astrignant cultivar. Moreover, hue angle $\left(H^{\circ}\right)$ of both 'Xiaofangshi' and 'Naiyoushi' was higher at harvest then decreased in different treatment during different ripening stages reflected the development in the color of fruit to deep orange. 


\section{Introduction:-}

Persimmon (Diospyros kaki L.) is a deciduous tree of the Ebenaceae family, it has been widely cultivated in East Asia. The fruits of Diospyros kaki are classified into astringent and non-astringent persimmon cultivars according to the presence of astringency in the fruits at harvest [1]. China, with its vast cultivable land and suitable climatic conditions is best suited for persimmon culture. Quality of persimmon is vital for consumer's acceptance and their increased consumption. The quality is determined by parameters like flavor, color, total soluble solids, titratable acidity, sugar/acid ratio, storability and nutritional value as reflected by minerals, vitamin $\mathrm{C}$ and sugar content. Fruit quality is the ultimate result of fruit setting, growth, development and maturation [2-5]. Therefore, this research was carried out to evaluate the main quality characteristic in different persimmon cultivars and to study the effect of ethylene and salicylic acid in main quality characteristic of two persimmon cultivars namely; 'Xiaofangshi' and 'Naiyoushi' during different ripening stage.

\section{Materials and methods:-}

Experiments were conducted in College of Horticulture and Plant Protection, Yangzhou University, Yangzhou, China during 2014-2016.

\section{Plant materials and sampling}

Persimmon fruit of 34 different cultivars were used in this research, including 8 non-astringent cultivars (namely Diospyros kaki cv. 'Chansiwanshi', 'Fuyoutianshi', 'Meiguohaikumanshi', 'Ribencilangshi', 'Ribenhuijinshenbuzhishi', 'Ribenruoshanxicilangshi', 'Ribenyangfengshi' and 'Shangxizaoshengshi') (Fig. 1) and 26 astringent cultivars (namely Diospyros kaki cv. 'Cangshantuoshi', 'Baoshandashuishi', 'Cexiangshuishi', 'Changanfojiandingshi', 'Changanqiuzhengshi', 'Gongchengyueshi', 'Gutianyadanshi', 'Haianxiaofangshi', 'Haiyangdabianshi', 'Hezebayuehuangshi', 'Jishanmimiguanshi', 'Jingchuanbiantatashi', 'Longhuiruanzaoshi', 'Mopanshi', 'Nanzhangchutoushi', 'Qidongshutouhongshi', 'Qiubeishuishi', 'Qujingniunaishi', 'Shengxianhuangtanshi', 'Xiangyangniuxinshi', 'Xingyangdayeshuishi', 'Xiuningbianshi', 'Yangshuoniuxinshi', 'Yongjibaishi', 'Yunyangdahuoguanshi' and 'Zhouqumomoshi') (Fig. 2). The fruits samples were harvested during ripening stage, in October 23, 2015 from National Germplasm Nursery of Persimmon (Yangling, Shaanxi, China).

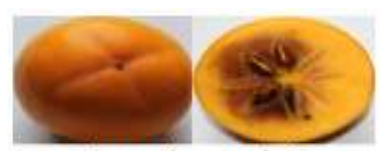

Chansiwanshi

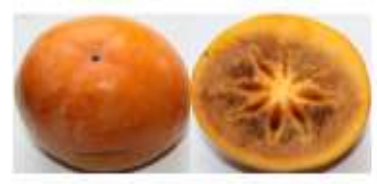

Ribenhuijinshenbuzhi Ribenruoshanxicilang

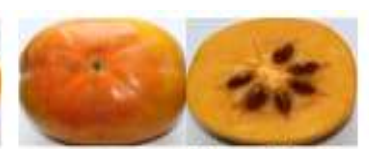

Fuyoutianshi

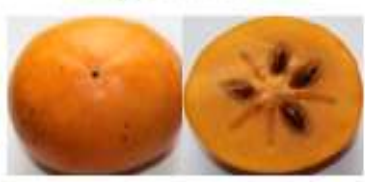

Fig. 1:- Photo of fruits of different non-astringent persimmon cultivars

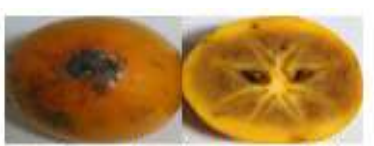

Meiguohaikumanshi

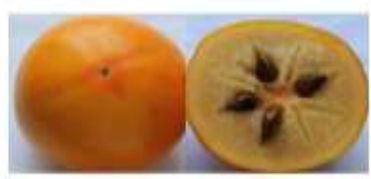

Ribenyangfengshi

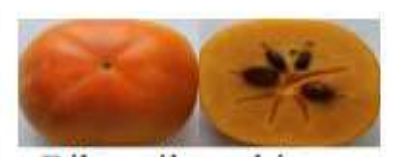

Ribencilangshi

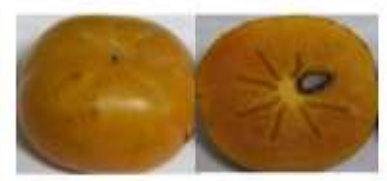

Shangxizaoshengshi 


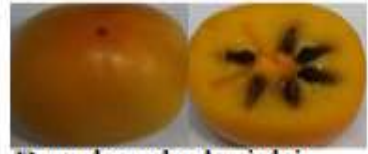

Baoshandashuishi

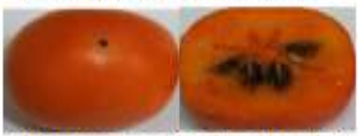

Changanqiuzhengshi

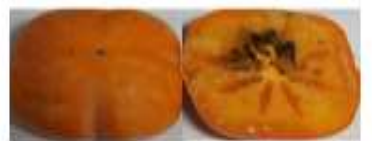

Haiyangdabianshi

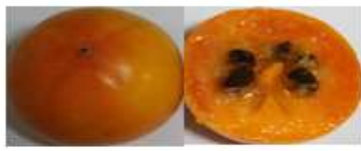

Longhuiruanzaoshi

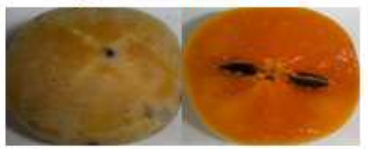

Qiubeishuishi

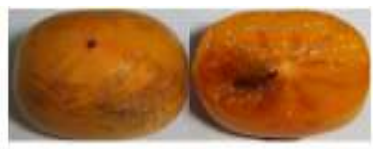

Xingyangdayeshuishi

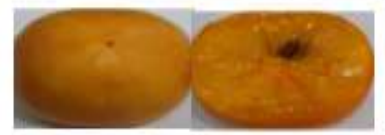

Yunyangdahuoguan

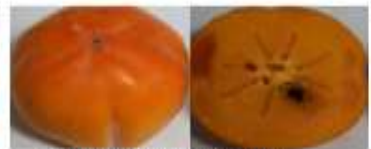

Cangshantuoshi

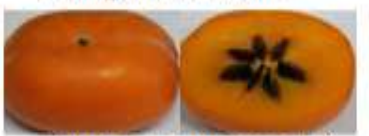

Gongchengyueshi

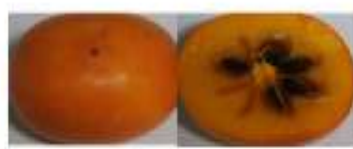

Hezebayuehuangshi
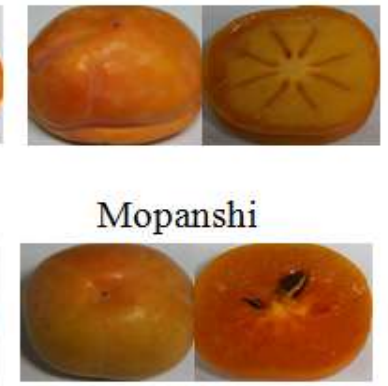

Qujingniunaishi

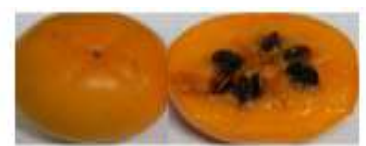

Xiuningbianshi

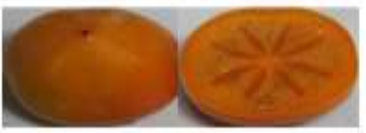

Zhouqumomoshi

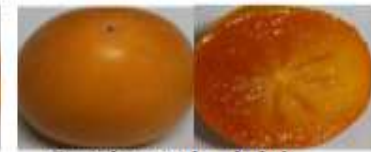

Cexiangshuishi

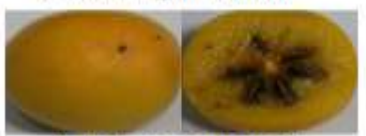

Gutianyadanshi

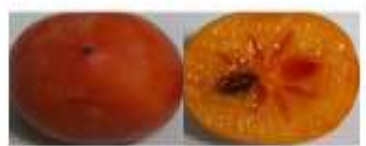

Jishanmimiguanshi Jingchuanbiantatashi
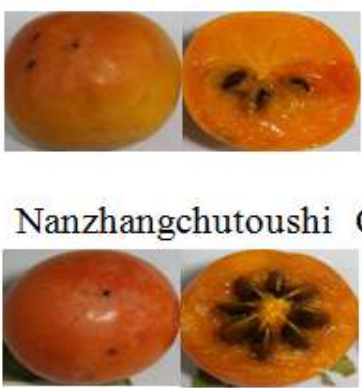

Shengxianhuangtan

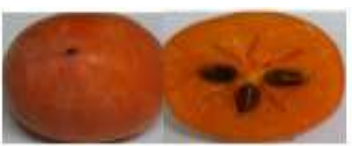

Yangshuoniuxinshi
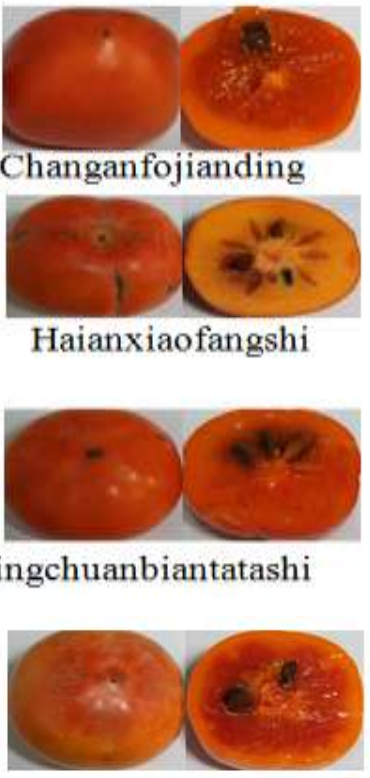

Changanfojianding

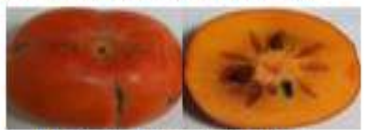

Haianxiaofangshi

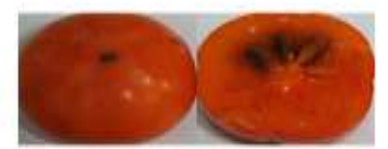

\section{Qidongshutouhongshi}

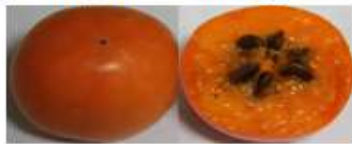

Xiangyangniuxin

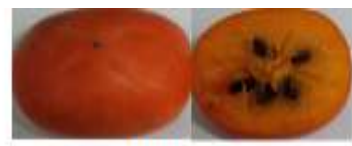

Yongjjibaishi

Fig. 2:- Photo of fruits of different astringent persimmon cultivars.

Moreover, the fruits of two cultivars namely 'Xiaofangshi' and 'Naiyoushi' was obtained from the orchard of Xinjie, Dongtai, Yancheng City, Jiangsu Province, China, the fruits were harvested after the first signs of chlorophyll breakdown at September 26 and October 13, 2014, respectively. After transportation to the laboratory, unblemished fruits were selected for some main fruit quality indices measurement including size, shape and color. The fruits of 'Xiaofangshi' and 'Naiyoushi' were randomly divided into three lots: one lot was treated with ultra pure water (control fruit), the second lot was treated with ethylene, the fruits were dipped in $25 \mathrm{~L}$ of an aqueous solution of $2 \mathrm{~g} \mathrm{~L}^{-1}$ Ethrel $48 \mathrm{SL}$ (Bayer Crop Science S.A.; ethephon, 2-chloroethyl phosphonic acid) and the last one was treated with $0.3 \mu \mathrm{L}$-1 salicylic acid both on the same day of harvest for 30 minutes. After each treatment, the fruits processed for ventilation till dry then each fruit was packed in $0.02 \mathrm{~mm}$ thick polyethylene bags and allowed to ripen at $20^{\circ} \mathrm{C}$. Fruits were collected at different ripening stage with an interval of about 3 days. 
Ten intact fruits were selected to determine the main quality indices of different cultivars of persimmon fruits and during different ripening stages.

\section{Assement of physical and chemical characteristics}

Determination of fruit weight: Fruit weight was determined using a top loading balance (Gandg Testing Instrument Factory, China).

Determination of fruit diameters: The vertical (length) and horizontal (width) diameters were measured by micrometer scale (Taizhou Xinshangliang Measuring Tools Co., Ltd., China).

Determination of fruit shape index: The fruit shape index is the ratio of the vertical and horizontal diameters.

Determination of seed number: Number of seeds was counted in each fruit of different cultivars.

Determination of fruit firmness: Firmness was measured using the Firm Tech II (BioWorks Inc., USA) provided with a flat tip of $2 \mathrm{~cm}$. Two measurements on each equatorial side were performed on each fruit. The mean of each replicate was recorded and expressed as newtons $(\mathrm{N}) \pm$ standard error $(\mathrm{SE})$.

Determination of total soluble solid (TSS): TSS was determined by a portable refractometer (Chengdu Optical Instrument Factory, China) and the measurements were performed on the opposite sides of the equatorial plane on each fruit.

Determination of titratable acidiy (TA): TA was determined according to the titration method [6] as follows: $5 \mathrm{~g}$ of the pulp was grinded to homogenate with $5 \mathrm{ml}$ distilled water. Subsequently, after filtration and centrifugation for 10 min at $10,000 \mathrm{rpm} / \mathrm{m}, 3 \mathrm{ml}$ of the supernatant was titrated against fresh $0.02 \mathrm{M} \mathrm{NaOH}$ to phenolphthaleine end point (pale permanent pink colour, $\mathrm{pH}$ 8.2). Each sample was repeated three times and calculated as follow: TA content $\%$ $=\mathrm{C} \times \mathrm{V}_{2} \times \mathrm{M} \times 10 / \mathrm{m} \times \mathrm{V}_{1}$, Where: $\mathrm{C}$ means concentration of $\mathrm{NaOH}, \mathrm{V}_{2}$ means $\mathrm{ml}$ of $\mathrm{NaOH}$ used, $\mathrm{M}$ means Molecular weight of $\mathrm{NaOH}$, m means sample weight and $\mathrm{V}_{1}$ means $\mathrm{ml}$ of juice.

\section{Assessment of fruit color}

The color of the opposite sides of the equatorial plane on each fruit were evaluated using a TC-P2A chroma meter (Beijing Optical Instrument Factory, China) using three color parameters including $L^{*}$ (lightness or darkness), $a^{*}$ (green or red) and $b^{*}$ (blue or yellow) values. These values were converted to hue angle degree $\left(H^{\circ}=\right.$ arctangent $\left.\left(b * / a^{*}\right)\right)$ and chroma values $\left(C^{*}=\left(a^{*^{2}}+b^{*^{2}}\right)^{1 / 2}\right)$ according to the methods reported previously [7, 8].

\section{Statistical Analysis}

Fruit weight, diameter, shape index, TSS, TA and fruit color were the mean value of ten fruits. All the other data were means of three replicates with standard error. Microsoft Excel (Microcal Software Inc., Northampton, MA, USA) was used to calculate standard error. Figures were drawn by Graphpadprism (SanDiego, CA, USA, version 7). 


\section{Results:-}

\section{Physical and chemical characteristics of persimmon fruits}

1.1 Physical and chemical characteristics of different persimmon cultivars

The fruit weight, size, shape, TSS and titratable acidity varied due to different persimmon cultivars, no matter whether astringent or non-astringent (Table S1). Results showed that, 'Mopianshi' had the largest fruit weight of $271.08 \mathrm{~g}$ and 'Gutianyadanshi' had the smallest fruit weight of $39.94 \mathrm{~g}$. While fruit shape index varied between 1.16 to 0.63 in 'Cexiangshuishi' and 'Jingchuanbiantatashi', respevtively. Firmness varied between $15.28 \mathrm{~N}$ to $2.34 \mathrm{~N}$ in 'Ribencilangshi' and 'Cangshantuoshi', respectively. 'Shengxianhuangtanshi' contain the highest number of seed, while, 'mopianshi', 'Yunyangdahuoguanshi' and 'Zhouqumomoshi' contain only one seed. On the other hand, TSS reached the highest value of 21.17 in 'Xingyangdayeshuishi' and the lowest value of 11.32 in 'Shangxizaoshengshi'. Moreover, results of titratable acidity showed that the values varied from 0.72 in 'Gongchengyueshi' to 0.11 in 'Haiyangdabianshi' and 'Longhuiruanzaoshi'. Generally, the average weight of fruit of non-astringent persimmon cultivars was heavier compared to astringent persimmon, while the differences in fruit shapes index among all the astringent persimmon cultivars was larger than that of non-astringent persimmon cultivars. Moreover, the average TSS of the astringent persimmon cultivars was higher than that of the non-astringent persimmons, while, TA was basically consistent in both non-astringent and astringent persimmon cultivars (Fig. 3).

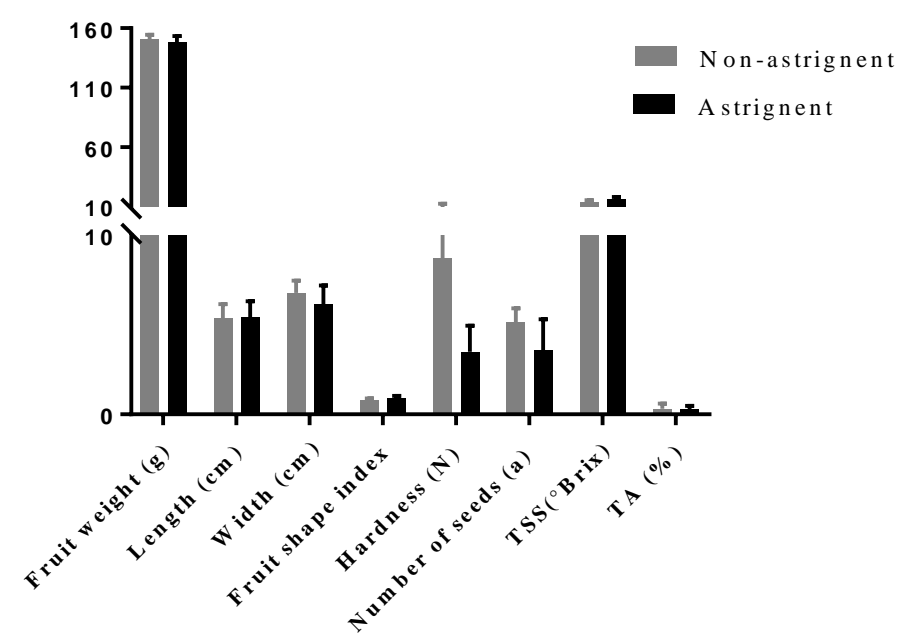

Fig. 3:- Basic fruit quality indices of non- astringent and astringent persimmon (Diospyros kaki L.).

1.2 Effect of Ethylene and Salicylic Acid in Physical and Chemical Characteristics of Two Persimmon Cultivars during Different Ripening Stages

There were no significant differences in fruit weight, length width and fruit shape index in different treatment in both two cultivars. However, in 'Xiaofangshi' the mean value vaired between 148.75-140.00, 48.61-41.06, 70.0364.7 and $0.73-0.68$, respectively. While, in 'Naiyoushi' the value varied between 191.86-180.03, 58.1-51.59, 70.9873.69, 0.79-0.73, respectively (Fig. 4 to Fig. 7). Generally, 'Naiyoushi' had higher value compared to 'Xiaofangshi'. On the other hand results showed significant differences in fruit firmness and total soluble solids in different treatment in both two cultivars (Fig. 8 \& Fig. 9). Fruit firmness decreased during different ripening stages of 
persimmon fruits, however, fruit treated with ethylene had the lowest firmness followed by control fruits, while, fruit treated with salicylic acid had the highest firmness. Total soluble solids progressively increased during different ripening stages of persimmon fruits, however, fruit treated with ethylene had the highest TSS followed by control fruits, while, fruit treated with salicylic acid had the lowest value. In 'Xiaofangshi' the highest TSS value were 13.36, 12.46, and 11.67, while, in 'Naiyoushi' the highest TSS value were 17.55, 16.13 and 15.48, respectively. Generally, 'Naiyoushi'had higher firmness and TSS compared to 'Xiaofangshi'.
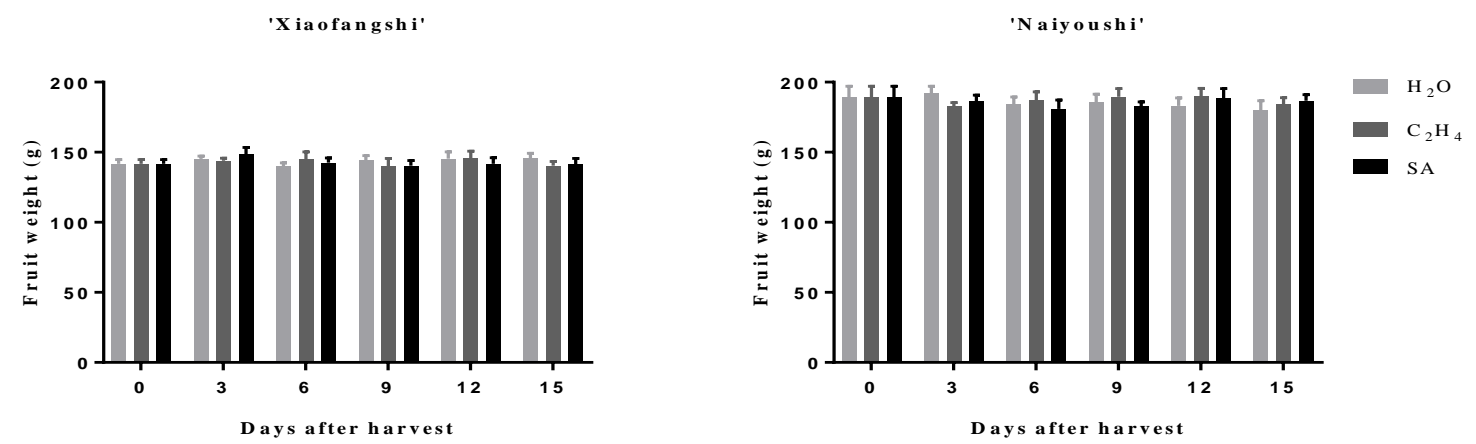

Fig. 4:- Effect of ethylene and salicylic acid on weight of persimmon (Diospyros kaki cv. 'Xaiofangshi' and

'Naiyoushi') fruits during different ripening stages.
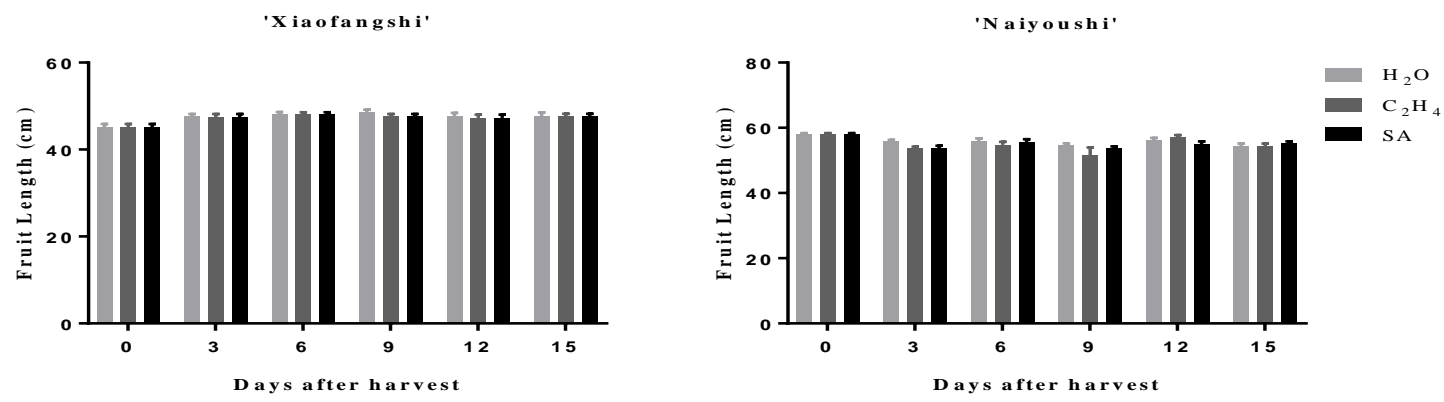

Fig. 5:- Effect of ethylene and salicylic acid on length of persimmon (Diospyros kaki cv. 'Xaiofangshi' and 'Naiyoushi') fruits during different ripening stages.
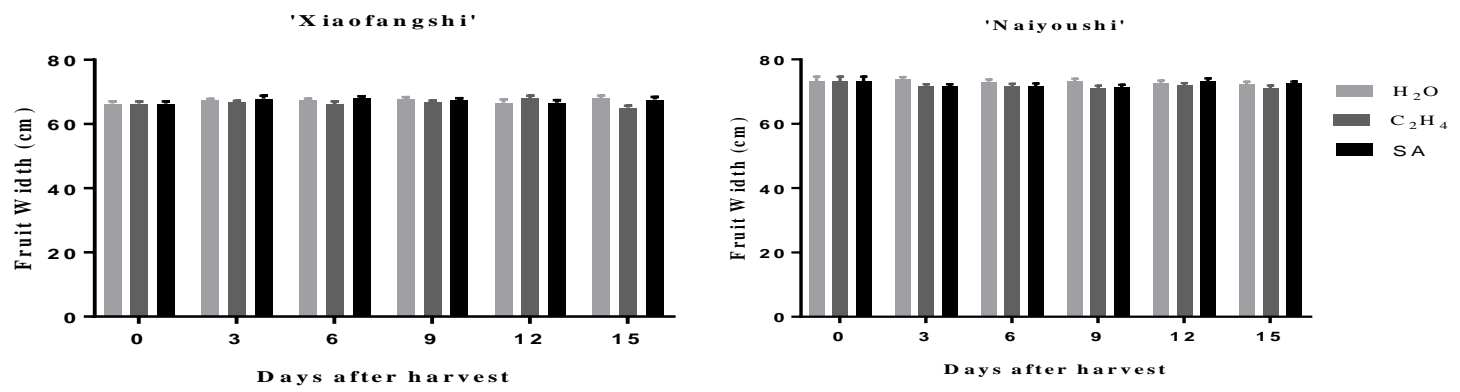

Fig. 6:- Effect of ethylene and salicylic acid on width of persimmon (Diospyros kaki cv. 'Xaiofangshi' and 'Naiyoushi') fruits during different ripening stages. 
'Xia ofangshi'

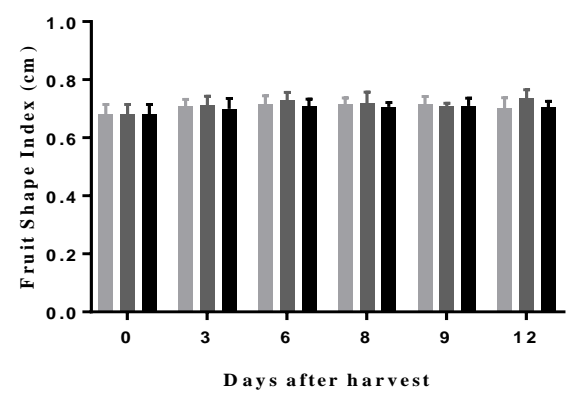

'Naiyoushi'

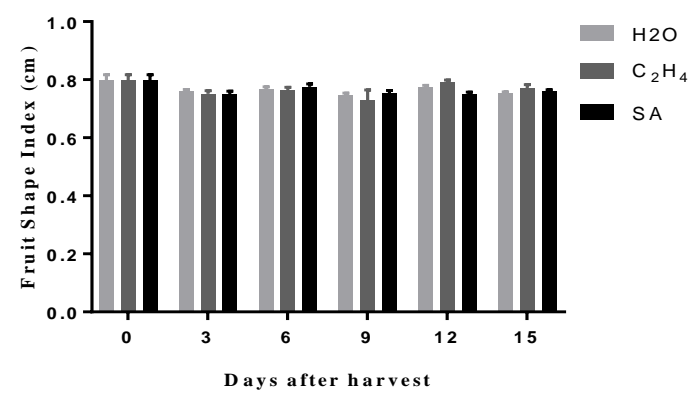

Fig. 7:- Effect of ethylene and salicylic acid on shape index of persimmon (Diospyros kaki cv. 'Xaiofangshi' and 'Naiyoushi') fruits during different ripening stages.
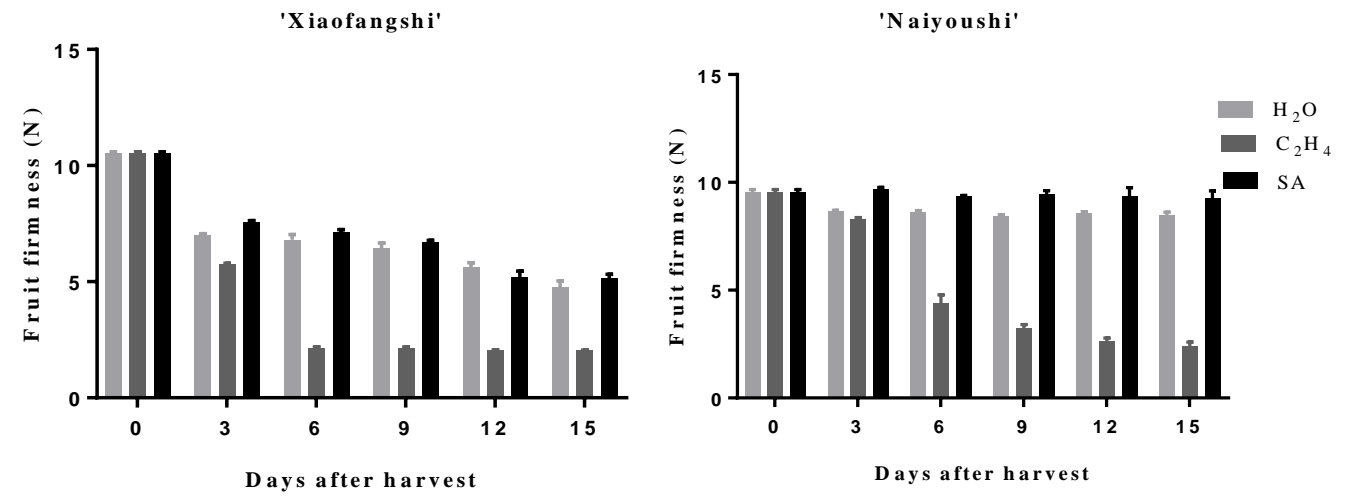

Fig. 8:- Effect of ethylene and salicylic acid on firmness of persimmon (Diospyros kaki cv. 'Xaiofangshi' and 'Naiyoushi') fruits during different ripening stages.
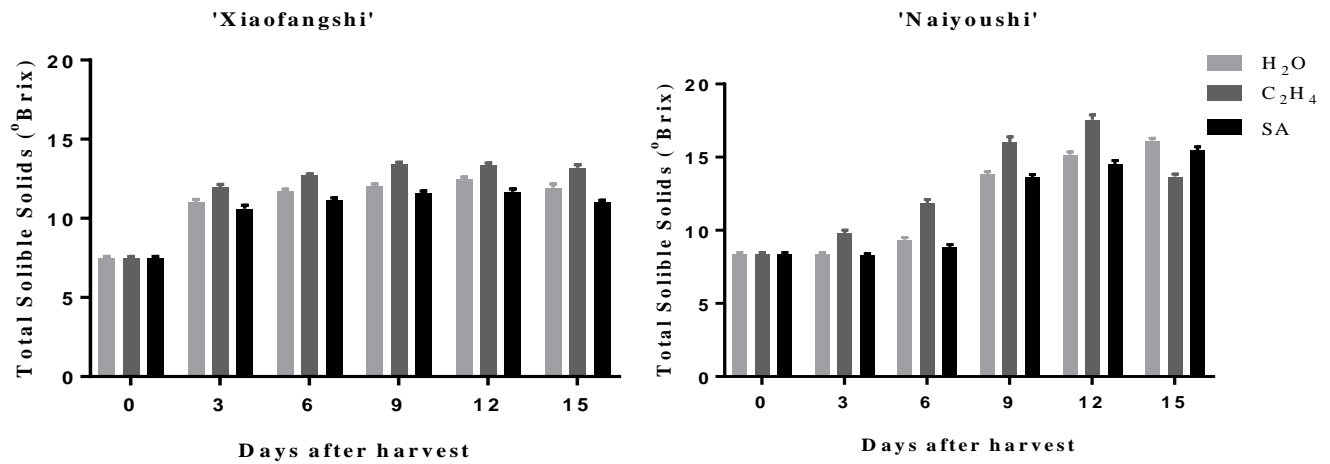

Fig. 9:- Effect of ethylene and salicylic acid on total soluble solids of persimmon (Diospyros kaki cv. 'Xaiofangshi' and 'Naiyoushi') fruits during different ripening stages. 


\section{Fruit color indices of persimmon fruits}

\subsection{Fruit color indices of different persimmon cultivars}

The main color indices $L^{*}, a^{*}$ and $b^{*}$ had a positive value in both fruits pulp and peel of different persimmon cultivars (Table S2 \& S3). However, in the pulp the highest value of $L^{*} a^{*}$ and $b^{*}$ were 66.09, 12.19 and 29.52 in 'Ribenruoshanxicilangshi', 'Yongjibaishi' and 'Ribenruoshanxicilangshi', respectively, and the lowest value were 32.61, 1.76 and 14.68 in 'Qujingniunaishi', 'Ribenyanfengshi' and 'Qiubeishuishi', respectively. While in the peel the highest value of $L^{*} a^{*}$ and $b^{*}$ were $64.00,20.65$ and 31.89 in 'Ribenkuaijinshenbuzhishi', 'Jingchuanbiantatashi' and 'Ribenkuaijinshenbuzhishi' and the lowest value were 44.84, 2.36 and 19.24 in 'Shengxianhuangtanshi', 'Shangxizaoshengshi' and 'Shengxianhuangtanshi', respectively. The mean color $a^{*} / b^{*}$, $H^{\circ}$ and $C^{*}$ values of fruits of different persimmon cultivars were also described. In the pulp the values of $\mathrm{a}^{*} / \mathrm{b}^{*}$ varied from 0.76 to 0.07 in 'Shengxianhuangtanshi' and 'Ribenyangfengshi', respectively. While, the value of $H^{\circ}$ varied from 179.12 in 'Ribenyangfengshi' to 1.19 in 'Qidongshutouhongshi', indicating that 'Ribenyangfengshi' tend more to green color while 'Qidongshutouhongshi' tend more to orange-red color. Whears the value of $C^{*}$ varied from 29.84 in 'Ribenruoshanxicilangshi' to 16.60 in 'Gongchengyueshi'. Generally, the pulp of astringent persimmon had deeper orange red color compared to non-astrignant. On the other hand, results of the the peel color showed that the values of $a^{*} / b^{*}$ varied from 0.96 in 'Shengxianhuangtanshi' to 0.08 in 'Shangxizaoshengshi' and $H^{\circ}$ varied from 174.82 in 'Shangxizaoshengshi' to 5.17 in 'Changanfujiandingshi', indicating that 'Shangxizaoshengshi' tend more to green color while 'Changanfujiandingshi' tend more to orange-red color. While, the value of $C^{*}$ varied from 33.40 in 'Yunyangdahuoguanshi' to 25.29 in 'Gongchengyueshi'. Generally, the peel of astringent persimmon had deeper orange red color compared to non-astringent (Fig. 10).

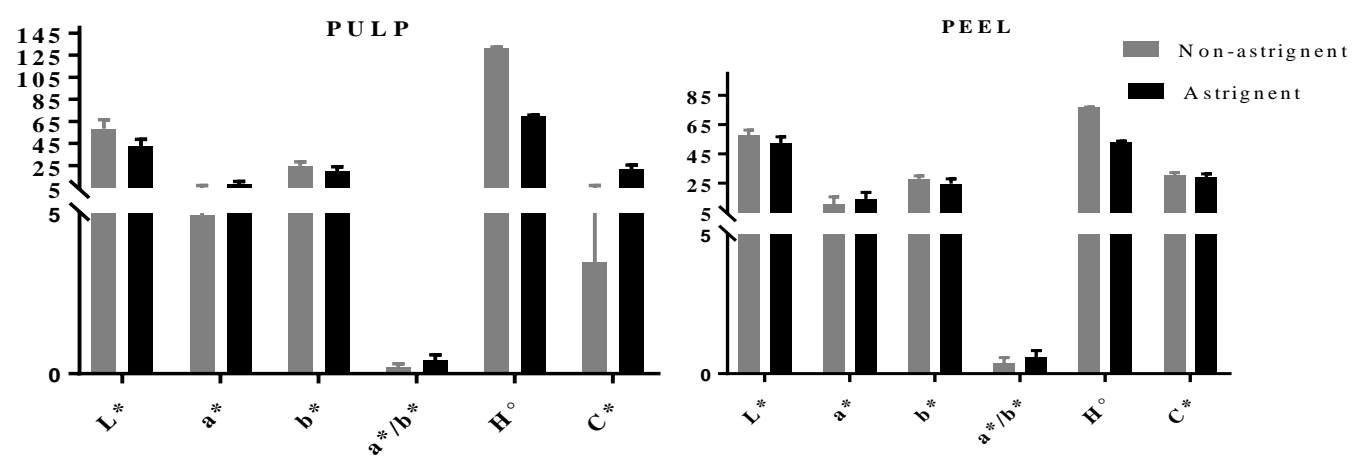

Fig. 10:- Basic color indices of non- astringent and astringent persimmon (Diospyros kaki L.) fruits.

\subsection{Fruit colour indices of persimmon fruits during different ripening stages}

In the pulp of 'Xiaofangshi' $L^{*}$ value was directly decreased after harvest, however, fruits treated with ethylene had the lowest value followed by control fruits and fruits treated with salicylic acid. While $L^{*}$ value was increased in the peel during different ripening stages. In both the pulp and the peel of the fruits $a^{*}$ directly change to positive value after 3 days and $b^{*}$ value trended similarly with $L^{*}$ value. In addition, the color was well described by $a^{*} / b^{*}$ ratio, results revealed that the ratio is negative at harvest and directly change to positive after 3 days in both the pulp and 
the peel of the fruits. Alternatively, the color also could be depicted by $H^{\circ}$ which was higher at harvest then decreaed in different treatment during different ripening stages. $C^{*}$ also represented the lightness which trended similarly with $L^{*}$ value. In 'Naiyoushi' $L^{*}$ value was decreased in the pulp during different ripening stages, however, fruits treated with ethylene had the lowest value followed by control fruits, then fruits treated with salicylic acid. While in the peel $L^{*}$ value was decreased in fruit treated with ethylene and slightly increased in control fruits and fruits treated with salicylic acids. In both the pulp and the peel of the fruits $a^{*}$ had positive value and $b^{*}$ value trended similarly with $L^{*}$ value. $a^{*} / b^{*}$ ratio was positive in both the pulp and the peel of the fruits. $C^{*}$ was trended similarly with $L^{*}$ value, and $\mathrm{H}^{\circ}$ decreased in different treatment during different ripening stages with lowest value in fruit treated with ethylene (Table S4 \& S5).

\section{Discussion:-}

Persimmon (Diospyros kaki L.) which could be divided into two types, namely, astringent persimmon and nonastringent persimmon, is widely cultivated in East Asia such as China, Korea and Japan [9, 10]. Persimmon is not only an important fruit, which is eaten as a fresh fruit, but also traditionally used for many medicinal purposes [11]. The physical and chemical characteristics of persimmon fruits are important in assessing fruit quality and identifying correlations between changes in these characteristics, making quality control easier. Various quality characteristics of persimmon cultivars including chemical composition, physical characteristics and volatile compounds have been previously studied [12-16].

In this research, results showed that the main fruit quality was varied among different persimmon cultivars. Generally, non-astringent persimmon cultivars had the highest average weight, while, astringent persimmon cultivars had the largest fruit shapes index and TSS. Moreover, results showed that there were no significant differences in main fruit quality including fruit weight, diameter and fruit shape index in two different cultivars during different ripening stages. Generally, 'Naiyoushi' had higher value compared to 'Xiaofangshi'. On the other hand, both fruit firmness and TSS showed significant differences in both two cultivars, result revealed that fruit treated with ethylene had the lowest firmness and the highest TSS followed by control fruits, while fruit treated with salicylic acid had the highest firmness and the lowest TSS. Generally, 'Naiyoushi' had higher firmness and TSS compared to 'Xiaofangshi'. Zhou et al., [17] showed that the fruit size, shape, TSS and TA content varied due to different persimmon cultivars, no matter whether astringent or non-astringent. The average weight of individual fruit of the astringent persimmon cultivars was heavier than that of the non-astringent persimmon and the differences in fruit shapes among all the astringent persimmon cultivars was larger than that among the non-astringent persimmon cultivars. The average TSS content of the astringent persimmon cultivars was lower than that of the non-astringent persimmon, while, TA was on the reverse trend. However, the great differences of quality indexes among different cultivars might result from genetic and geographical origins. Flesh firmness at harvest is an important criterion to maintain quality during the postharvest period. Celik and Ercisli found the skin and flesh firmness of cv. Hachiya as 59.4 and $36.3 \mathrm{~N}$, respectively [14]. The flesh firmness of persimmon cv. Harbiye decreased during fruit growth and reached 51-54 $\mathrm{N}$ in the third week of October [13]. On the other hand, ethylene plays important roles in the regulation of plant development and senescence [18] and profoundly affects the quality of harvested products [19]. It 
has been widely accepted that ethylene plays an important role during the ripening of climacteric fruit, initiating and coordinating diverse processes such as color development, softening and aroma formation. Persimmon is a climacteric fruit that has a short shelf-life due to accelerated fruit softening. Ethylene plays a critical role in fruit softening of persimmon [20]. This softening process is accelerated after the removal of astringency, and significantly influences the acceptability of the fruit. As expected in previous studies, ethylene production in 'Pingxiangli' pear reached a peak on day 6 of the 12-day ripening period and then decreased. The ethylene production rate decreased on day 12. Similarly, fruit firmness decreased dramatically from $19.58 \mathrm{~N}$ at harvest to $3.24 \mathrm{~N}$ on day 6 and then remained the same for the rest of the ripening period [21]. On the other hand, application of salicylic acid is useful in inhibiting tissue softening in fruits by reducing cell wall hydrolases activities and maintaining cell membrane consistency [22]. In tomato fruit ascorbic acid content, total soluble solid, titratable acidity, firmness and $L^{*}$ (lightness) retained by salicylic acid treatments [23]. Babalar et al. [24] reported that the use of salicylic acid decrease TSS of strawberry fruits and consequently, effectively delays fruit senescence process. Treatment of kiwifruits maintained a lower TSS content than the control fruits at the end of cold storage [25].

To analyze the development of fruit color, the color of the pulp and surface of the peel of persimmon fruits was measured with a colorimeter, which provided $L^{*}, a^{*}$ and $b^{*}$ values. These values were converted to $H^{\circ}$ and $\mathrm{C}^{*}$, which quantify the intensity or purity of the hue [7]. In the uniform color space, $L^{*}$ represented the lightness, $a^{*}$ represented ratio of red/magenta and green and $b^{*}$ represented ratio of yellow and blue. A comparison of fruit color between different persimmon cultivars showed that both the pulp and the peel of astringent persimmon had deeper orange red color compared to non-astrignant. Moreover, $\mathrm{H}^{\circ}$ was higher at harvest then decreaed in different treatment during different ripening stages reflected the development in the color of fruit to deep orange. The color of persimmon fruit ranges from yellow, orange to deep red [9], which, mainly results from carotenoids accumulation [26]. Therefore, high carotenoids content, not only play an important role in biological property, but also are favored from the marketing perspective $[27,28]$. A comparison of fruit color between "Niuxinshi" and "Nishimurawase"; representatives of astringent and non-astringent varieties showed that they had similar tendency, but only had differences in quantity. With the development of fruit, $L^{*}$ value was constantly increased, but declined when fruit color deepened. $a^{*}$ was negative value and constantly growth which showed that the fruit color changed from green to red. $b^{*}$ value trended similarly with $L^{*}$ value, which revealed that the fruit color was yellow and gradually deepening, and $\mathrm{C}^{*}$ also represented the lightness which trended similarly with $L^{*}$ value. [29]. In addition, the color was well described by $a^{*} / b^{*}$ ratio which was negative for green fruits, zero for yellow fruits, and positive for orange fruits [30]. Alternatively, the color also could be depicted by $H^{\circ}$ as follows: $0^{\circ}$ for reddish-purple, $90^{\circ}$ for yellow, $180^{\circ}$ for bluish-green and $270^{\circ}$ for blue [31, 32]. These two values all showed that the fruit color of both "Niuxinshi" and "Nishimurawase" changed from green to yellow, and "Nishimurawase" was more evident [29]. In 'Pingxiangli' pear hue angle decreased during fruit ripening. The change in hue angle reflected the change in the skin color of 'Pingxiangli' fruit from green to yellow-green [21]. 


\section{Acknowledgement:-}

This research was financially supported by the National Natural Science Foundation of China (Grant no. 31372042) and the Excellent Youth Backbone Teachers of Yangzhou University (2014). The authors are grateful to Yong Yang (National Germplasm Nursery of Persimmon) and Xiao Chunliu (Xinjie Agricultural Technology Extension Center) helping collect fruit samples.

Table S1:- Basic fruit quality indices of different cultivars of persimmon (Diospyros kaki L.)

\begin{tabular}{|c|c|c|c|c|c|c|c|c|}
\hline Cultivars & $\begin{array}{l}\text { Fruit } \\
\text { weight }(g)\end{array}$ & \begin{tabular}{|l|}
$\begin{array}{l}\text { Length } \\
\text { (cm) }\end{array}$ \\
\end{tabular} & $\begin{array}{l}\text { Width } \\
\text { (cm) }\end{array}$ & $\begin{array}{l}\text { Fruit } \\
\text { shape } \\
\text { index }\end{array}$ & $\begin{array}{l}\text { Firmnes } \\
\mathrm{s}(\mathrm{N})\end{array}$ & $\begin{array}{l}\text { Numbe } \\
\mathbf{r} \text { of } \\
\text { seeds }\end{array}$ & $\begin{array}{l}\text { TSS } \\
\left({ }^{\circ} \text { Brix }\right)\end{array}$ & $\begin{array}{l}\text { TA } \\
(\%)\end{array}$ \\
\hline \multicolumn{9}{|l|}{ Non-astrnigent } \\
\hline Chansiwan & $\begin{array}{l}144.69 \pm 18 . \\
13\end{array}$ & $\begin{array}{l}5.58 \pm 3.5 \\
8\end{array}$ & $\begin{array}{l}6.56 \pm 2 . \\
78\end{array}$ & $\begin{array}{l}0.85 \pm 0 . \\
05\end{array}$ & $\begin{array}{l}6.42 \pm 0.3 \\
6\end{array}$ & $\begin{array}{l}6.50 \pm 1 . \\
08\end{array}$ & $\begin{array}{l}11.62 \pm 0 . \\
38\end{array}$ & $\begin{array}{l}0.24 \pm 0 . \\
01\end{array}$ \\
\hline Fuyoutianshi & $\begin{array}{l}121.56 \pm 19 . \\
02\end{array}$ & \begin{tabular}{|l}
$4.64 \pm 2.2$ \\
2
\end{tabular} & $\begin{array}{l}6.66 \pm 3 . \\
72\end{array}$ & $\begin{array}{l}0.70 \pm 0 . \\
03\end{array}$ & $\begin{array}{l}4.70 \pm 0.3 \\
2\end{array}$ & $\begin{array}{l}5.70 \pm 1 . \\
41\end{array}$ & $\begin{array}{l}15.36 \pm 0 \\
32\end{array}$ & $\begin{array}{l}0.14 \pm 0 . \\
02\end{array}$ \\
\hline Meiguohaikuman & $\begin{array}{l}218.93 \pm 20 . \\
66\end{array}$ & $\begin{array}{l}7.15 \pm 4.1 \\
6\end{array}$ & $\begin{array}{l}7.19 \pm 2 . \\
04\end{array}$ & $\begin{array}{l}0.99 \pm 0 . \\
04\end{array}$ & $\begin{array}{l}11.32 \pm 0 \\
10\end{array}$ & $\begin{array}{l}4.83 \pm 2 . \\
04\end{array}$ & $\begin{array}{l}16.60 \pm 0 \\
73\end{array}$ & $\begin{array}{l}0.16 \pm 0 . \\
04\end{array}$ \\
\hline Ribencilang & $\begin{array}{l}185.27 \pm 26 \\
40\end{array}$ & $\begin{array}{l}5.12 \pm 2.0 \\
9\end{array}$ & $\begin{array}{l}7.55 \pm 2 . \\
99\end{array}$ & $\begin{array}{l}0.68 \pm 0 . \\
01\end{array}$ & $\begin{array}{l}15.28 \pm 0 . \\
16\end{array}$ & $\begin{array}{l}4.50 \pm 1 . \\
76\end{array}$ & $\begin{array}{l}15.17 \pm 0 \\
46\end{array}$ & $\begin{array}{l}0.28 \pm 0 . \\
01\end{array}$ \\
\hline $\begin{array}{l}\text { Ribenkuaijinshenb } \\
\text { uzhi }\end{array}$ & $78.25 \pm 6.66$ & $\begin{array}{l}4.69 \pm 1.3 \\
5\end{array}$ & $\begin{array}{l}5.45 \pm 1 . \\
84\end{array}$ & $\begin{array}{l}0.86 \pm 0 . \\
04\end{array}$ & $\begin{array}{l}5.56 \pm 0.3 \\
3\end{array}$ & $\begin{array}{l}4.20 \pm 1 . \\
23\end{array}$ & $\begin{array}{l}12.28 \pm 0 \\
29\end{array}$ & $\begin{array}{l}1.17 \pm 0 . \\
01\end{array}$ \\
\hline $\begin{array}{l}\text { Ribenruoshanxicìla } \\
\text { ng }\end{array}$ & $\begin{array}{l}182.92 \pm 15 \\
46\end{array}$ & $\begin{array}{l}5.18 \pm 2.3 \\
4\end{array}$ & $\begin{array}{l}7.58 \pm 2 \\
27\end{array}$ & $\begin{array}{l}0.68 \pm 0 . \\
03\end{array}$ & $\begin{array}{l}8.08 \pm 0.9 \\
4\end{array}$ & $\begin{array}{l}5.80 \pm 1 . \\
14\end{array}$ & $\begin{array}{l}13.26 \pm 0 \\
43\end{array}$ & $\begin{array}{l}0.15 \pm 0 . \\
02\end{array}$ \\
\hline Ribenyanfeng & $\begin{array}{l}144.69 \pm 12 . \\
76\end{array}$ & \begin{tabular}{|l|}
$5.67 \pm 2.1$ \\
5
\end{tabular} & $\begin{array}{l}6.79 \pm 2 . \\
31\end{array}$ & $\begin{array}{l}0.83 \pm 0 . \\
03\end{array}$ & $\begin{array}{l}12.44 \pm 0 . \\
20\end{array}$ & $\begin{array}{l}4.62 \pm 1 . \\
06\end{array}$ & $\begin{array}{l}12.91 \pm 0 \\
42\end{array}$ & $\begin{array}{l}0.14 \pm 0 . \\
01\end{array}$ \\
\hline Shangxizaosheng & $\begin{array}{l}126.70 \pm 10 . \\
24\end{array}$ & $\begin{array}{l}4.82 \pm 1.6 \\
5\end{array}$ & $\begin{array}{l}6.67 \pm 2 . \\
13\end{array}$ & $\begin{array}{l}0.72 \pm 0 . \\
02\end{array}$ & $\begin{array}{l}6.16 \pm 0.4 \\
6\end{array}$ & $\begin{array}{l}5.10 \pm 0 . \\
99\end{array}$ & $\begin{array}{l}11.32 \pm 0 \\
42\end{array}$ & $\begin{array}{l}0.23 \pm 0 . \\
01\end{array}$ \\
\hline Average value & $\begin{array}{l}150.38 \pm 4.1 \\
3\end{array}$ & \begin{tabular}{|l|}
$5.36 \pm 0.8$ \\
2
\end{tabular} & $\begin{array}{l}6.81 \pm 0 . \\
68\end{array}$ & $\begin{array}{l}0.79 \pm 0 . \\
11\end{array}$ & $\begin{array}{l}8.74 \pm 3.8 \\
2\end{array}$ & $\begin{array}{l}5.16 \pm 0 . \\
78\end{array}$ & $\begin{array}{l}13.56 \pm 1 \\
93\end{array}$ & $\begin{array}{l}0.31 \pm 0 . \\
35\end{array}$ \\
\hline \multicolumn{9}{|l|}{ Astringent } \\
\hline Baoshandashuish & $\begin{array}{l}126.60 \pm 23 \\
43\end{array}$ & $\begin{array}{l}5.32 \pm 2.5 \\
2\end{array}$ & $\begin{array}{l}5.91 \pm 3 . \\
97\end{array}$ & $\begin{array}{l}0.90 \pm 0 . \\
04\end{array}$ & $\begin{array}{l}4.52 \pm 0.1 \\
8\end{array}$ & $\begin{array}{l}4.83 \pm 0 . \\
75\end{array}$ & $\begin{array}{l}17.08 \pm 0 \\
34\end{array}$ & $\begin{array}{l}0.66 \pm 0 . \\
03\end{array}$ \\
\hline Cangshantuoshi & $\begin{array}{l}170.64 \pm 29 . \\
99\end{array}$ & $\begin{array}{l}5.70 \pm 5.1 \\
3\end{array}$ & $\begin{array}{l}6.68 \pm 5 \\
06\end{array}$ & $\begin{array}{l}0.85 \pm 0 . \\
05\end{array}$ & $\begin{array}{l}2.34 \pm 0.1 \\
3\end{array}$ & $\begin{array}{l}1.57 \pm 1 \\
81\end{array}$ & $\begin{array}{l}16.64 \pm 0 \\
48\end{array}$ & $\begin{array}{l}0.58 \pm 0 . \\
02\end{array}$ \\
\hline Cexiangshuishi & $96.16 \pm 8.54$ & $\begin{array}{l}5.91 \pm 1.3 \\
0\end{array}$ & $\begin{array}{l}5.10 \pm 2 . \\
60\end{array}$ & $\begin{array}{l}1.16 \pm 0 . \\
07\end{array}$ & $\begin{array}{l}2.38 \pm 0.1 \\
9\end{array}$ & $\begin{array}{l}3.38 \pm 1 \\
60\end{array}$ & $\begin{array}{l}13.50 \pm 0 \\
30\end{array}$ & $\begin{array}{l}0.48 \pm 0 . \\
01\end{array}$ \\
\hline Changanfujianding & $\begin{array}{l}179.95 \pm 15 \text {. } \\
01\end{array}$ & \begin{tabular}{|l}
$6.73 \pm 1.4$ \\
3
\end{tabular} & $\begin{array}{l}6.26 \pm 2 \\
01\end{array}$ & $\begin{array}{l}1.08 \pm 0 . \\
03\end{array}$ & $\begin{array}{l}5.28 \pm 0.2 \\
2\end{array}$ & $\begin{array}{l}4.17 \pm 2 . \\
23\end{array}$ & $\begin{array}{l}16.38 \pm 0 \\
26\end{array}$ & $\begin{array}{l}0.36 \pm 0 . \\
01\end{array}$ \\
\hline $\begin{array}{l}\text { Changanqiuzhengb } \\
\text { ing }\end{array}$ & $\begin{array}{l}145.80 \pm 13 . \\
02\end{array}$ & $\begin{array}{l}5.63 \pm 3.9 \\
2\end{array}$ & $\begin{array}{l}6.21 \pm 2 . \\
32\end{array}$ & $\begin{array}{l}0.91 \pm 0 . \\
04\end{array}$ & $\begin{array}{l}2.68 \pm 0.1 \\
3\end{array}$ & $\begin{array}{l}4.60 \pm 1 . \\
14\end{array}$ & $\begin{array}{l}16.70 \pm 0 \\
41\end{array}$ & $\begin{array}{l}0.68 \pm 0 . \\
04\end{array}$ \\
\hline Gongchengyue shi & $\begin{array}{l}114.24 \pm 11 . \\
8\end{array}$ & $\begin{array}{l}4.60 \pm 1.8 \\
0\end{array}$ & $\begin{array}{l}5.70 \pm 2 . \\
18\end{array}$ & $\begin{array}{l}0.81 \pm 0 . \\
03\end{array}$ & $\begin{array}{l}3.46 \pm 0.2 \\
0\end{array}$ & $\begin{array}{l}4.86 \pm 2 . \\
19\end{array}$ & $\begin{array}{l}17.39 \pm 0 \\
24\end{array}$ & $\begin{array}{l}0.72 \pm 0 . \\
02\end{array}$ \\
\hline Gutianyadanshi & $39.94 \pm 6.37$ & $\begin{array}{l}4.29 \pm 2.3 \\
8\end{array}$ & $\begin{array}{l}3.83 \pm 2 . \\
67\end{array}$ & $\begin{array}{l}1.12 \pm 0 . \\
08\end{array}$ & $\begin{array}{l}2.46 \pm 0.1 \\
7\end{array}$ & $\begin{array}{l}5.00 \pm 1 . \\
56\end{array}$ & $\begin{array}{l}15.30 \pm 0 . \\
44\end{array}$ & $\begin{array}{l}0.26 \pm 0 . \\
04\end{array}$ \\
\hline Haianxiaofangshi & $\begin{array}{l}187.64 \pm 24 . \\
07\end{array}$ & \begin{tabular}{|l|}
$5.21 \pm 2.7$ \\
6
\end{tabular} & $\begin{array}{l}6.95 \pm 3 . \\
90\end{array}$ & $\begin{array}{l}0.75 \pm 0 . \\
06\end{array}$ & $\begin{array}{l}2.66 \pm 0.1 \\
7\end{array}$ & $\begin{array}{l}4.00 \pm 1 . \\
58\end{array}$ & $\begin{array}{l}17.20 \pm 0 . \\
48\end{array}$ & $\begin{array}{l}0.18 \pm 0 . \\
02\end{array}$ \\
\hline Haiyangdabianshi & $\begin{array}{l}175.12 \pm 8.8 \\
7\end{array}$ & $\begin{array}{l}4.61 \pm 2.0 \\
9\end{array}$ & $\begin{array}{l}7.15 \pm 2 . \\
21\end{array}$ & $\begin{array}{l}0.64 \pm 0 . \\
03\end{array}$ & $\begin{array}{l}2.46 \pm 0.3 \\
0\end{array}$ & $\begin{array}{l}4.17 \pm 1 . \\
33\end{array}$ & $\begin{array}{l}14.83 \pm 0 \\
38\end{array}$ & $\begin{array}{l}0.11 \pm 0 . \\
02\end{array}$ \\
\hline Hezebayuehuang & $\begin{array}{l}74.53 \pm 14.0 \\
8\end{array}$ & $\begin{array}{l}4.12 \pm 1.4 \\
4\end{array}$ & $\begin{array}{l}5.04 \pm 3 . \\
98\end{array}$ & $\begin{array}{l}0.82 \pm 0 . \\
05\end{array}$ & $\begin{array}{l}5.36 \pm 0.2 \\
8\end{array}$ & $\begin{array}{l}2.60 \pm 1 . \\
17\end{array}$ & $\begin{array}{l}13.88 \pm 0 \\
38\end{array}$ & $\begin{array}{l}0.16 \pm 0 . \\
05\end{array}$ \\
\hline Jìshānmìmiguàn & $68.09 \pm 9.78$ & $\begin{array}{l}5.11 \pm 2.1 \\
4\end{array}$ & $\begin{array}{l}4.60 \pm 2 . \\
80\end{array}$ & $\begin{array}{l}1.11 \pm 0 . \\
05\end{array}$ & $\begin{array}{l}2.60 \pm 0.2 \\
3\end{array}$ & $\begin{array}{l}2.70 \pm 1 . \\
77\end{array}$ & $\begin{array}{l}16.50 \pm 0 \\
29\end{array}$ & $\begin{array}{l}0.19 \pm 0 . \\
03\end{array}$ \\
\hline
\end{tabular}




\begin{tabular}{|l|l|l|l|l|l|l|l|l|}
\hline Jingchuanbiantata & $118.49 \pm 15$. & $4.01 \pm 2.8$ & $6.34 \pm 3$. & $0.63 \pm 0$. & $3.65 \pm 0.2$ & $4.75 \pm 2$. & $15.78 \pm 0$. & $0.21 \pm 0$. \\
& 08 & 0 & 30 & 03 & 1 & 12 & 39 & 05 \\
\hline Longhuiruanzao & $152.61 \pm 14$. & $5.68 \pm 2.9$ & $6.46 \pm 2$. & $0.88 \pm 0$. & $2.54 \pm 0.2$ & $6.00 \pm 0$. & $13.46 \pm 0$. & $0.11 \pm 0$. \\
& 74 & 7 & 59 & 04 & 8 & 82 & 33 & 02 \\
\hline Mopanshi & $271.08 \pm 19$. & $6.26 \pm 5.8$ & $8.11 \pm 3$. & $0.77 \pm 0$. & $4.47 \pm 0.1$ & $1.00 \pm 0$. & $13.50 \pm 0$. & $0.27 \pm 0$. \\
& 57 & 89 & 62 & 10 & 5 & 08 & 40 & 01 \\
\hline Nanzhangchutoush & $237.96 \pm 23$. & $6.83 \pm 4.6$ & $7.66 \pm 3$. & $0.89 \pm 0$. & $2.58 \pm 0.2$ & $1.40 \pm 0$. & $14.75 \pm 0$. & $0.36 \pm 0$. \\
i & 65 & 9 & 34 & 07 & 2 & 05 & 47 & 02 \\
\hline Qidongshutouhong & $206.00 \pm 13$. & $6.14 \pm 7.6$ & $6.87 \pm 1$. & $0.89 \pm 0$. & $2.58 \pm 0.1$ & $2.00 \pm 1$. & $17.00 \pm 0$. & $0.15 \pm 0$. \\
shi & 02 & 5 & 91 & 10 & 9 & 63 & 20 & 01 \\
\hline Qiubeishuishi & $141.51 \pm 14$. & $4.82 \pm 2.5$ & $6.53 \pm 2$. & $0.74 \pm 0$. & $2.41 \pm 0.2$ & $1.86 \pm 1$. & $14.75 \pm 0$. & $0.19 \pm 0$. \\
& 39 & 6 & 60 & 04 & 6 & 21 & 35 & 02 \\
\hline Qujingniunaishi & $129.03 \pm 25$. & $4.51 \pm 2.8$ & $6.17 \pm 5$. & $0.73 \pm 0$. & $2.54 \pm 0.2$ & $3.71 \pm 1$. & $15.71 \pm 0$. & $0.36 \pm 0$. \\
& 07 & 2 & 45 & 04 & 4 & 38 & 30 & 01 \\
\hline Shengxianhuangta & $46.38 \pm 2.36$ & $4.11 \pm 1.8$ & $4.14 \pm 0$. & $0.99 \pm 0$. & $2.61 \pm 0.2$ & $6.80 \pm 0$. & $17.08 \pm 0$. & $0.22 \pm 0$. \\
nshi & & 0 & 68 & 03 & 6 & 92 & 39 & 05 \\
\hline Xiangyagniuxinshi & $207.64 \pm 28$. & $6.50 \pm 4.5$ & $6.83 \pm 3$. & $0.95 \pm 0$. & $2.60 \pm 0.2$ & $4.40 \mathrm{v} 2$. & $16.55 \pm 2$. & $0.15 \pm 0$. \\
& 45 & 2 & 22 & 04 & 0 & 20 & 21 & 02 \\
\hline Xingyangdayeshui & $144.25 \pm 24$. & $5.45 \pm 3.2$ & $5.98 \pm 4$. & $0.92 \pm 0$. & $3.58 \pm 0.1$ & $2.00 \pm 0$. & $21.17 \pm 0$. & $0.17 \pm 0$. \\
shi & 17 & 4 & 88 & 08 & 9 & 26 & 64 & 01 \\
\hline Xiuningbianshi & $157.68 \pm 9.2$ & $4.81 \pm 1.4$ & $6.75 \pm 2$. & $0.71 \pm 0$. & $2.57 \pm 0.1$ & $6.33 \pm 0$. & $18.62 \pm 0$. & $0.21 \pm 0$. \\
& 1 & 0 & 23 & 04 & 7 & 52 & 47 & 01 \\
\hline Yangshuo & $118.86 \pm 8.0$ & $6.02 \pm 1.3$ & $5.55 \pm 1$. & $1.08 \pm 0$. & $8.36 \pm 0.1$ & $3.71 \pm 0$. & $20.11 \pm 0$. & $0.15 \pm 0$. \\
niuxinshi & 3 & 3 & 65 & 04 & 2 & 70 & 43 & 04 \\
\hline Yongjibaishi & $162.46 \pm 16$. & $5.19 \pm 1.6$ & $6.87 \pm 3$. & $0.76 \pm 0$. & $3.44 \pm 0.2$ & $5.40 \pm 0$. & $15.35 \pm 0$. & $0.19 \pm 0$. \\
& 15 & 2 & 43 & 03 & 1 & 55 & 28 & 01 \\
\hline Yunyangdahuogua & $248.30 \pm 12$. & $7.38 \pm 3.5$ & $7.22 \pm 0$. & $1.02 \pm 0$. & $5.48 \pm 0.2$ & $1.00 \pm 0$. & $15.00 \pm 0$. & $0.37 \pm 0$. \\
nshi & 67 & 8 & 87 & 06 & 6 & 12 & 35 & 02 \\
\hline Zhouqumomoshi & $127.84 \pm 11$. & $6.12 \pm 3.2$ & $5.64 \pm 2$. & $1.08 \pm 0$. & $5.40 \pm 0.2$ & $1.00 \pm 0$. & $17.85 \pm 0$. & $0.22 \pm 0$. \\
& 61 & 7 & 05 & 03 & 5 & 02 & 28 & 03 \\
\hline Average value & $148.03 \pm 5.3$ & $5.42 \pm 0.9$ & $6.18 \pm 1$. & $0.89 \pm 0$. & $3.50 \pm 1.4$ & $3.59 \pm 1$. & $16.23 \pm 1$. & $0.30 \pm 0$. \\
& 2 & 2 & 03 & 15 & 7 & 73 & 90 & 18 \\
\hline
\end{tabular}

Table S2:- Fruit pulp color indices of different persimmon (Diospyros kaki L.) cultivars.

\begin{tabular}{|l|l|l|l|l|l|l|}
\hline Cultivars & $\boldsymbol{L}^{*}$ & $\boldsymbol{a}^{*}$ & $\boldsymbol{b}^{*}$ & $\boldsymbol{a}^{*} / \boldsymbol{b}^{*}$ & $\boldsymbol{H}^{\circ}$ & $\mathbf{C}^{*}$ \\
\hline Non-astringent & & & & & & \\
\hline Chansiwanshi & $46.62 \pm 3.31$ & $7.34 \pm 1.15$ & $18.87 \pm 1.77$ & $0.39 \pm 0.08$ & $70.97 \pm 0.07$ & $20.29 \pm 1.62$ \\
\hline Fuyoutianshi & $59.37 \pm 3.40$ & $4.75 \pm 2.96$ & $25.29 \pm 0.80$ & $0.19 \pm 0.12$ & $139.33 \pm 0.11$ & $25.88 \pm 1.01$ \\
\hline Meiguohaikumanshi & $46.21 \pm 2.46$ & $4.28 \pm 1.12$ & $20.03 \pm 1.04$ & $0.21 \pm 0.06$ & $129.61 \pm 0.06$ & $20.51 \pm 1.00$ \\
\hline Ribencilangshi & $63.02 \pm 4.36$ & $3.48 \pm 1.74$ & $27.47 \pm 1.37$ & $0.13 \pm 0.06$ & $160.28 \pm 0.06$ & $27.73 \pm 1.37$ \\
\hline Ribenkuaijinshenbuzhishi & $64.81 \pm 6.18$ & $7.09 \pm 2.50$ & $26.99 \pm 2.77$ & $0.27 \pm 0.12$ & $111.00 \pm 0.11$ & $28.05 \pm 2.25$ \\
\hline Ribenruoshanxicilangshi & $66.09 \pm 3.78$ & $3.67 \pm 2.28$ & $29.52 \pm 1.24$ & $0.13 \pm 0.08$ & $160.46 \pm 0.08$ & $29.84 \pm 1.00$ \\
\hline Ribenyanfengshi & $65.78 \pm 2.32$ & $1.76 \pm 0.72$ & $24.05 \pm 1.64$ & $0.07 \pm 0.03$ & $179.12 \pm 0.03$ & $24.12 \pm 1.63$ \\
\hline Shangxizaoshengshi & $55.03 \pm 2.69$ & $7.22 \pm 2.09$ & $24.92 \pm 1.76$ & $0.29 \pm 0.08$ & $104.78 \pm 0.08$ & $26.01 \pm 1.95$ \\
\hline Average value & $58.37 \pm 8.24$ & $4.95 \pm 2.07$ & $24.64 \pm 3.64$ & $0.21 \pm 0.10$ & $131.94 \pm 0.35$ & $25.30 \pm 3.47$ \\
\hline Astringent & & & & & & \\
\hline Baoshandashuishi & $46.77 \pm 2.30$ & $3.76 \pm 2.17$ & $21.60 \pm 2.17$ & $0.17 \pm 0.09$ & $144.42 \pm 0.09$ & $22.00 \pm 2.36$ \\
\hline Cangshantuoshi & $48.99 \pm 4.86$ & $10.88 \pm 4.08$ & $24.91 \pm 2.37$ & $0.45 \pm 0.21$ & $57.55 \pm 0.16$ & $27.48 \pm 1.70$ \\
\hline Cexiangshuishi & $39.74 \pm 3.10$ & $6.10 \pm 2.72$ & $17.02 \pm 2.37$ & $0.37 \pm 0.16$ & $80.90 \pm 0.14$ & $18.25 \pm 2.44$ \\
\hline Changanfujiandingshi & $36.88 \pm 1.74$ & $8.91 \pm 3.77$ & $16.08 \pm 1.55$ & $0.57 \pm 0.29$ & $26.04 \pm 0.20$ & $18.70 \pm 1.45$ \\
\hline Changanqiuzhengbingshi & $43.11 \pm 1.50$ & $8.85 \pm 3.75$ & $20.11 \pm 2.30$ & $0.45 \pm 0.22$ & $57.68 \pm 0.18$ & $22.24 \pm 2.12$ \\
\hline Gongchengyueshi & $36.91 \pm 2.73$ & $4.72 \pm 3.61$ & $15.50 \pm 2.66$ & $0.33 \pm 0.28$ & $97.54 \pm 0.24$ & $16.60 \pm 2.21$ \\
\hline Gutianyadanshi & $46.65 \pm 2.25$ & $3.55 \pm 1.44$ & $22.06 \pm 1.69$ & $0.16 \pm 0.07$ & $147.62 \pm 0.07$ & $22.39 \pm 1.64$ \\
\hline
\end{tabular}




\begin{tabular}{|l|l|l|l|l|l|l|}
\hline Haianxiaofangshi & $37.62 \pm 3.72$ & $11.81 \pm 5.91$ & $16.89 \pm 3.07$ & $0.70 \pm 1.93$ & $14.26 \pm 0.48$ & $20.61 \pm 6.66$ \\
\hline Haiyangdabianshi & $54.60 \pm 4.14$ & $8.33 \pm 4.52$ & $26.56 \pm 2.28$ & $0.31 \pm 0.16$ & $98.91 \pm 0.14$ & $28.07 \pm 3.10$ \\
\hline Hezebayuehuangshi & $46.16 \pm 2.65$ & $8.76 \pm 4.39$ & $23.08 \pm 1.98$ & $0.38 \pm 0.18$ & $77.87 \pm 0.16$ & $24.99 \pm 2.61$ \\
\hline Jishanmimiguanshi & $38.63 \pm 2.79$ & $8.21 \pm 3.25$ & $17.62 \pm 2.16$ & $0.47 \pm 0.19$ & $50.14 \pm 0.16$ & $19.66 \pm 2.40$ \\
\hline Jingchuanbiantatashi & $39.37 \pm 4.17$ & $9.17 \pm 5.51$ & $18.16 \pm 3.31$ & $0.49 \pm 0.22$ & $46.88 \pm 0.17$ & $20.63 \pm 5.24$ \\
\hline Longhuiruanzaoshi & $39.05 \pm 1.71$ & $6.23 \pm 2.80$ & $17.18 \pm 2.06$ & $0.37 \pm 0.18$ & $79.64 \pm 0.16$ & $18.47 \pm 1.84$ \\
\hline Mopanshi & $48.01 \pm 1.61$ & $3.90 \pm 2.83$ & $24.27 \pm 1.34$ & $0.16 \pm 0.12$ & $148.41 \pm 0.11$ & $24.71 \pm 1.38$ \\
\hline Nanzhangchutoushi & $51.17 \pm 0.54$ & $6.86 \pm 3.10$ & $24.88 \pm 1.13$ & $0.28 \pm 0.13$ & $109.61 \pm 0.12$ & $25.95 \pm 1.32$ \\
\hline Qidongshutouhongshi & $38.52 \pm 4.76$ & $10.79 \pm 3.66$ & $17.09 \pm 3.36$ & $0.67 \pm 0.31$ & $1.19 \pm 0.21$ & $20.55 \pm 2.50$ \\
\hline Qiubeishuishi & $36.09 \pm 3.04$ & $8.47 \pm 3.21$ & $14.68 \pm 3.20$ & $0.63 \pm 0.37$ & $14.52 \pm 0.23$ & $17.30 \pm 2.52$ \\
\hline Qujingniunaishi & $32.61 \pm 8.57$ & $7.16 \pm 3.70$ & $17.14 \pm 1.86$ & $0.43 \pm 0.24$ & $64.40 \pm 0.20$ & $18.90 \pm 1.71$ \\
\hline Shengxianhuangtanshi & $34.41 \pm 2.59$ & $11.60 \pm 4.81$ & $15.25 \pm 2.42$ & $0.76 \pm 0.28$ & $21.77 \pm 0.20$ & $19.49 \pm 3.88$ \\
\hline Xiangyagniuxinshi & $36.30 \pm 5.99$ & $10.34 \pm 5.42$ & $16.32 \pm 4.24$ & $0.62 \pm 0.20$ & $8.19 \pm 0.15$ & $19.52 \pm 6.14$ \\
\hline Xingyangdayeshuishi & $38.88 \pm 4.85$ & $5.75 \pm 2.50$ & $17.54 \pm 3.41$ & $0.35 \pm 0.18$ & $87.77 \pm 0.16$ & $18.64 \pm 3.07$ \\
\hline Xiuningbianshi & $48.80 \pm 0.75$ & $5.37 \pm 2.67$ & $22.87 \pm 1.67$ & $0.24 \pm 0.13$ & $122.14 \pm 0.12$ & $23.63 \pm 1.39$ \\
\hline Yangshuoniuxinshi & $49.96 \pm 2.90$ & $11.25 \pm 2.23$ & $25.72 \pm 2.03$ & $0.44 \pm 0.10$ & $56.83 \pm 0.08$ & $28.16 \pm 1.86$ \\
\hline Yongjibaishi & $40.11 \pm 2.93$ & $12.19 \pm 3.82$ & $20.21 \pm 0.73$ & $0.60 \pm 0.18$ & $13.92 \pm 0.14$ & $23.77 \pm 2.26$ \\
\hline Yunyangdahuoguan & $54.50 \pm 0.73$ & $4.08 \pm 1.87$ & $27.95 \pm 0.82$ & $0.15 \pm 0.07$ & $153.38 \pm 0.07$ & $28.29 \pm 0.78$ \\
\hline Zhouqumomoshi & $41.55 \pm 2.12$ & $9.22 \pm 1.92$ & $19.01 \pm 1.92$ & $0.49 \pm 0.10$ & $43.30 \pm 0.08$ & $21.18 \pm 2.12$ \\
\hline Average value & $42.52 \pm 6.30$ & $7.93 \pm 2.71$ & $19.99 \pm 3.94$ & $0.42 \pm 0.17$ & $70.19 \pm 0.47$ & $21.93 \pm 3.56$ \\
\hline
\end{tabular}

Table S3:- Fruit peel color indices of different persimmon (Diospyros kaki L.) cultivars.

\begin{tabular}{|c|c|c|c|c|c|c|}
\hline Cultivars & $L^{*}$ & $a^{*}$ & $b^{*}$ & $a * / b^{*}$ & $\boldsymbol{H}^{\circ}$ & $\mathrm{C}^{*}$ \\
\hline \multicolumn{7}{|l|}{ Non-astringent } \\
\hline Chansiwanshi & $58.92 \pm 1.80$ & $5.22 \pm 1.75$ & $26.86 \pm 1.60$ & $0.19 \pm 0.06$ & $136.78 \pm 0.06$ & $27.41 \pm 1.70$ \\
\hline Fuyoutianshi & $55.55 \pm 0.88$ & $14.96 \pm 2.13$ & $26.48 \pm 0.93$ & $0.56 \pm 0.08$ & $20.97 \pm 0.06$ & $30.47 \pm 1.36$ \\
\hline Meiguohaikumanshi & $57.57 \pm 2.07$ & $10.58 \pm 2.24$ & $27.98 \pm 1.50$ & $0.38 \pm 0.10$ & $74.82 \pm 0.09$ & $30.00 \pm 0.72$ \\
\hline Ribencilangshi & $51.36 \pm 7.57$ & $15.66 \pm 3.86$ & $25.03 \pm 1.53$ & $0.63 \pm 0.17$ & $6.00 \pm 0.12$ & $29.70 \pm 2.10$ \\
\hline Ribenkuaijinshenbuzhishi & $64.00 \pm 1.36$ & $7.84 \pm 3.42$ & $31.89 \pm 1.19$ & $0.24 \pm 0.10$ & $119.85 \pm 0.09$ & $32.97 \pm 1.80$ \\
\hline Ribenruoshanxicilangshi & $58.17 \pm 2.56$ & $12.51 \pm 2.50$ & $26.99 \pm 1.38$ & $0.47 \pm 0.11$ & $49.47 \pm 0.09$ & $29.85 \pm 1.12$ \\
\hline Ribenyanfengshi & $57.91 \pm 0.84$ & $15.39 \pm 3.22$ & $29.02 \pm 0.72$ & $0.53 \pm 0.12$ & $30.79 \pm 0.09$ & $32.98 \pm 1.07$ \\
\hline Shangxizaoshengshi & $58.53 \pm 0.92$ & $2.36 \pm 1.90$ & $28.00 \pm 1.12$ & $0.08 \pm 0.07$ & $174.82 \pm 0.07$ & $28.16 \pm 1.04$ \\
\hline Average value & $57.75 \pm 3.52$ & $10.56 \pm 5.01$ & $27.78 \pm 2.04$ & $0.38 \pm 0.20$ & $76.69 \pm 0.24$ & $30.19 \pm 1.99$ \\
\hline \multicolumn{7}{|l|}{ Astringent } \\
\hline Baoshandashuishi & $59.15 \pm 1.08$ & $5.74 \pm 2.20$ & $29.99 \pm 0.51$ & $0.19 \pm 0.08$ & $137.45 \pm 0.07$ & $30.60 \pm 0.35$ \\
\hline Cangshantuoshi & $45.74 \pm 2.83$ & $18.26 \pm 5.16$ & $20.05 \pm 3.01$ & $0.90 \pm 0.16$ & $55.46 \pm 0.09$ & $27.21 \pm 5.50$ \\
\hline Cexiangshuishi & $53.37 \pm 2.28$ & $11.66 \pm 6.39$ & $25.92 \pm 1.66$ & $0.45 \pm 0.24$ & $59.23 \pm 0.20$ & $28.93 \pm 3.23$ \\
\hline Changanfujiandingshi & $48.49 \pm 1.67$ & $14.64 \pm 3.08$ & $21.97 \pm 1.64$ & $0.67 \pm 0.16$ & $5.17 \pm 0.11$ & $26.54 \pm 1.89$ \\
\hline Changanqiuzhengbingshi & $50.77 \pm 1.77$ & $16.95 \pm 2.27$ & $23.73 \pm 1.54$ & $0.72 \pm 0.12$ & $17.44 \pm 0.08$ & $29.24 \pm 1.51$ \\
\hline Gongchengyueshi & $47.03 \pm 1.21$ & $12.93 \pm 1.59$ & $21.70 \pm 0.50$ & $0.60 \pm 0.07$ & $12.50 \pm 0.05$ & $25.29 \pm 0.98$ \\
\hline Gutianyadanshi & $58.08 \pm 1.04$ & $7.27 \pm 2.76$ & $29.95 \pm 0.81$ & $0.24 \pm 0.10$ & $119.91 \pm 0.09$ & $30.93 \pm 0.70$ \\
\hline Haianxiaofangshi & $48.38 \pm 3.16$ & $20.46 \pm 5.99$ & $22.29 \pm 2.09$ & $0.92 \pm 2.86$ & $61.89 \pm 0.34$ & $30.26 \pm 6.35$ \\
\hline Haiyangdabianshi & $51.05 \pm 3.51$ & $20.58 \pm 4.04$ & $24.10 \pm 2.71$ & $0.86 \pm 0.14$ & $47.60 \pm 0.08$ & $31.79 \pm 4.01$ \\
\hline Hezebayuehuangshi & $53.44 \pm 1.77$ & $15.82 \pm 3.20$ & $26.16 \pm 1.33$ & $0.61 \pm 0.16$ & $10.51 \pm 0.10$ & $30.73 \pm 1.12$ \\
\hline Jishanmimiguanshi & $47.22 \pm 1.39$ & $15.33 \pm 4.20$ & $20.93 \pm 1.41$ & $0.74 \pm 0.23$ & $19.01 \pm 0.16$ & $26.22 \pm 1.94$ \\
\hline Jingchuanbiantatashi & $47.73 \pm 1.28$ & $20.65 \pm 4.81$ & $22.21 \pm 1.22$ & $0.92 \pm 0.18$ & $60.51 \pm 0.10$ & $30.45 \pm 3.95$ \\
\hline Longhuiruanzaoshi & $53.59 \pm 1.79$ & $15.31 \pm 6.23$ & $25.69 \pm 1.07$ & $0.60 \pm 0.25$ & $16.98 \pm 0.19$ & $30.37 \pm 2.65$ \\
\hline Mopanshi & $56.59 \pm 3.01$ & $6.92 \pm 3.03$ & $27.43 \pm 1.99$ & $0.25 \pm 0.10$ & $117.84 \pm 0.10$ & $28.39 \pm 2.37$ \\
\hline Nanzhangchutoushi & $61.45 \pm 2.10$ & $10.42 \pm 3.05$ & $30.86 \pm 1.21$ & $0.34 \pm 0.11$ & $88.35 \pm 0.10$ & $32.69 \pm 0.90$ \\
\hline Qidongshutouhongshi & $51.34 \pm 0.45$ & $13.38 \pm 3.44$ & $24.19 \pm 1.39$ & $0.55 \pm 0.13$ & $25.77 \pm 0.10$ & $27.74 \pm 2.57$ \\
\hline Qiubeishuishi & $50.34 \pm 2.07$ & $8.61 \pm 3.75$ & $21.87 \pm 2.13$ & $0.40 \pm 0.18$ & $71.42 \pm 0.16$ & $23.75 \pm 2.19$ \\
\hline Qujingniunaishi & $52.91 \pm 1.51$ & $10.32 \pm 4.39$ & $25.03 \pm 1.16$ & $0.42 \pm 0.18$ & $66.39 \pm 0.16$ & $27.37 \pm 1.32$ \\
\hline Shengxianhuangtanshi & $44.84 \pm 1.26$ & $18.49 \pm 3.23$ & $19.24 \pm 1.22$ & $0.96 \pm 0.18$ & $68.13 \pm 0.09$ & $26.78 \pm 2.50$ \\
\hline
\end{tabular}




\begin{tabular}{|l|l|l|l|l|l|l|}
\hline Xiangyagniuxinshi & $49.42 \pm 1.64$ & $18.30 \pm 1.47$ & $22.79 \pm 1.24$ & $0.80 \pm 0.09$ & $37.98 \pm 0.05$ & $29.26 \pm 1.12$ \\
\hline Xingyangdayeshuishi & $51.18 \pm 4.55$ & $11.86 \pm 4.06$ & $24.62 \pm 3.83$ & $0.47 \pm 0.12$ & $49.00 \pm 0.10$ & $27.42 \pm 4.98$ \\
\hline Xiuningbianshi & $57.06 \pm 1.63$ & $10.27 \pm 3.43$ & $28.32 \pm 1.00$ & $0.36 \pm 0.13$ & $80.94 \pm 0.11$ & $30.28 \pm 0.96$ \\
\hline Yangshuoniuxinshi & $53.97 \pm 1.96$ & $15.75 \pm 2.19$ & $23.21 \pm 1.94$ & $0.68 \pm 0.14$ & $9.19 \pm 0.09$ & $28.15 \pm 1.44$ \\
\hline Yongjibaishi & $49.10 \pm 0.52$ & $20.20 \pm 2.62$ & $22.82 \pm 0.68$ & $0.89 \pm 0.14$ & $54.36 \pm 0.08$ & $30.54 \pm 1.42$ \\
\hline Yunyangdahuoguanshi & $59.12 \pm 2.62$ & $13.37 \pm 3.63$ & $30.46 \pm 0.52$ & $0.44 \pm 0.13$ & $57.56 \pm 0.10$ & $33.40 \pm 1.27$ \\
\hline Zhouqumomoshi & $53.21 \pm 3.39$ & $14.19 \pm 5.33$ & $25.40 \pm 2.20$ & $0.58 \pm 0.28$ & $24.07 \pm 0.19$ & $29.53 \pm 1.28$ \\
\hline Average value & $52.10 \pm 4.43$ & $14.14 \pm 4.42$ & $24.65 \pm 3.26$ & $0.60 \pm 0.23$ & $52.87 \pm 0.78$ & $28.99 \pm 2.29$ \\
\hline
\end{tabular}

Table S4:- Pulp and peel color indices of persimmon (Diospyros kaki cv. 'Xiaofangshi') fruits during different ripening stages.

\begin{tabular}{|c|c|c|c|c|c|c|c|}
\hline Treatment & $\begin{array}{l}\text { Ripening } \\
\text { stages }\end{array}$ & $L^{*}$ & $a^{*}$ & $b^{*}$ & $a^{* / b} b^{*}$ & $\mathrm{H}^{o}$ & $\mathbf{C}^{*}$ \\
\hline \multicolumn{8}{|l|}{ Pulp } \\
\hline \multirow[t]{6}{*}{$\mathrm{H}_{2} \mathrm{O}$} & 0 & $74.18 \pm 0.52$ & $-6.63 \pm 0.53$ & $27.72 \pm 0.42$ & $-0.24 \pm 0.02$ & $103.47 \pm 1.09$ & $28.54 \pm 0.4$ \\
\hline & 3 & $58.45 \pm 5.5$ & $6.86 \pm 1.09$ & $25.82 \pm 2.58$ & $0.35 \pm 0.09$ & $72.22 \pm 4.32$ & $27.21 \pm 2.21$ \\
\hline & 6 & $67.77 \pm 1.31$ & $6.46 \pm 0.66$ & $30.16 \pm 0.28$ & $0.21 \pm 0.02$ & $77.99 \pm 1.16$ & $30.9 \pm 0.34$ \\
\hline & 9 & $65.29 \pm 2.11$ & $6.95 \pm 1.07$ & $30.42 \pm 0.96$ & $0.24 \pm 0.04$ & $76.89 \pm 2.29$ & $31.41 \pm 0.8$ \\
\hline & 12 & $50.37 \pm 5.3$ & $6.8 \pm 0.59$ & $23.44 \pm 2.89$ & $0.56 \pm 0.07$ & $61.55 \pm 2.88$ & $26.38 \pm 2.74$ \\
\hline & 15 & $65.47 \pm 1.4$ & $10.33 \pm 1.11$ & $30.88 \pm 0.24$ & $0.34 \pm 0.04$ & $71.63 \pm 1.94$ & $32.72 \pm 0.3$ \\
\hline \multirow[t]{6}{*}{$\mathrm{C}_{2} \mathrm{H}_{4}$} & 0 & $74.18 \pm 0.52$ & $-6.63 \pm 0.53$ & $27.72 \pm 0.42$ & $-0.24 \pm 0.02$ & $103.47 \pm 1.09$ & $28.54 \pm 0.4$ \\
\hline & 3 & $59.02 \pm 5.17$ & $5.95 \pm 0.69$ & $26.38 \pm 2.29$ & $0.27 \pm 0.06$ & $75.5 \pm 2.87$ & $27.29 \pm 2.07$ \\
\hline & 6 & $30.56 \pm 0.41$ & $11.04 \pm 1.1$ & $11.53 \pm 0.45$ & $0.99 \pm 0.14$ & $47.35 \pm 3.55$ & $16.24 \pm 0.64$ \\
\hline & 9 & $32.85 \pm 0.53$ & $6.8 \pm 0.59$ & $12.71 \pm 0.55$ & $0.56 \pm 0.07$ & $61.55 \pm 2.97$ & $14.59 \pm 0.28$ \\
\hline & 12 & $31.57 \pm 0.89$ & $8.94 \pm 0.74$ & $12.43 \pm 0.8$ & $0.77 \pm 0.09$ & $53.85 \pm 3.55$ & $15.58 \pm 0.49$ \\
\hline & 15 & $30.03 \pm 0.63$ & $10.56 \pm 0.28$ & $11.39 \pm 0.62$ & $0.94 \pm 0.05$ & $46.89 \pm 1.26$ & $15.57 \pm 0.59$ \\
\hline \multirow[t]{6}{*}{ SA } & 0 & $74.18 \pm 0.52$ & $-6.63 \pm 0.53$ & $27.72 \pm 0.42$ & $-0.24 \pm 0.02$ & $103.47 \pm 1.09$ & $28.54 \pm 0.4$ \\
\hline & 3 & $58.62 \pm 4.76$ & $6.73 \pm 1.2$ & $26.59 \pm 2.16$ & $0.31 \pm 0.08$ & $55.78 \pm 16.46$ & $27.93 \pm 1.75$ \\
\hline & 6 & $67.63 \pm 1.24$ & $6.39 \pm 0.68$ & $30.47 \pm 0.26$ & $0.21 \pm 0.02$ & $78.2 \pm 1.24$ & $31.2 \pm 0.27$ \\
\hline & 9 & $67.07 \pm 0.99$ & $4.92 \pm 0.7$ & $31.58 \pm 0.3$ & $0.16 \pm 0.02$ & $81.14 \pm 1.3$ & $32.03 \pm 0.26$ \\
\hline & 12 & $52.61 \pm 5.39$ & $10.47 \pm 0.89$ & $23.94 \pm 2.93$ & $0.52 \pm 0.08$ & $63.56 \pm 3.55$ & $26.49 \pm 2.69$ \\
\hline & 15 & $64.78 \pm 1.19$ & $11.88 \pm 0.83$ & $31.23 \pm 0.32$ & $0.38 \pm 0.03$ & $69.19 \pm 1.5$ & $33.51 \pm 0.17$ \\
\hline \multicolumn{8}{|l|}{ Peel } \\
\hline \multirow[t]{6}{*}{$\mathrm{H}_{2} \mathrm{O}$} & 0 & $50.69 \pm 0.52$ & $-9.81 \pm 0.22$ & $22.8 \pm 0.37$ & $-0.43 \pm 0.01$ & $113.29 \pm 0.55$ & $24.82 \pm 0.36$ \\
\hline & 3 & $51.90 \pm 1.90$ & $1.40 \pm 2.32$ & $24.46 \pm 1.43$ & $0.09 \pm 0.11$ & $85.77 \pm 5.83$ & $25.57 \pm 1.21$ \\
\hline & 6 & $57.23 \pm 0.46$ & $4.39 \pm 0.77$ & $27.12 \pm 0.35$ & $0.09 \pm 0.03$ & $112.84 \pm 17.5$ & $27.32 \pm 0.31$ \\
\hline & 9 & $60.33 \pm 0.60$ & $4.39 \pm 1.42$ & $30.17 \pm 0.44$ & $0.14 \pm 0.05$ & $82.07 \pm 2.55$ & $30.76 \pm 0.58$ \\
\hline & 12 & $55.85 \pm 2.85$ & $11.27 \pm 1.52$ & $27.92 \pm 1.97$ & $0.44 \pm 0.07$ & $67.13 \pm 3.57$ & $30.58 \pm 1.72$ \\
\hline & 15 & $61.65 \pm 0.54$ & $8.2925 \pm 1.25$ & $31.26 \pm 0.34$ & $0.26 \pm 0.04$ & $75.45 \pm 2.05$ & $32.52 \pm 0.59$ \\
\hline \multirow[t]{6}{*}{$\mathrm{C}_{2} \mathrm{H}_{4}$} & 0 & $50.69 \pm 0.52$ & $-9.81 \pm 0.22$ & $22.8 \pm 0.37$ & $-0.43 \pm 0.01$ & $113.29 \pm 0.55$ & $24.82 \pm 0.36$ \\
\hline & 3 & $52.69 \pm 2.01$ & $0.708 \pm 1.97$ & $25.07 \pm 1.33$ & $0.06 \pm 0.09$ & $86.97 \pm 4.83$ & $25.84 \pm 1.16$ \\
\hline & 6 & $36.69 \pm 0.34$ & $11.934 \pm 0.4$ & $13.78 \pm 0.35$ & $0.87 \pm 0.04$ & $49.13 \pm 1.36$ & $18.28 \pm 0.31$ \\
\hline & 9 & $37.49 \pm 0.54$ & $10.21 \pm 0.88$ & $14.87 \pm 0.42$ & $0.7 \pm 0.07$ & $55.76 \pm 2.92$ & $18.26 \pm 0.31$ \\
\hline & 12 & $36.74 \pm 0.4$ & $12.37 \pm 0.56$ & $14.2 \pm 0.33$ & $0.88 \pm 0.05$ & $49.07 \pm 1.73$ & $18.91 \pm 0.32$ \\
\hline & 15 & $38.06 \pm 0.8$ & $12.62 \pm 0.69$ & $14.46 \pm 0.69$ & $0.89 \pm 0.06$ & $48.94 \pm 1.95$ & $19.29 \pm 0.74$ \\
\hline \multirow[t]{6}{*}{ SA } & 0 & $50.69 \pm 0.52$ & $-9.81 \pm 0.22$ & $22.8 \pm 0.37$ & $-0.43 \pm 0.01$ & $113.29 \pm 0.55$ & $24.82 \pm 0.36$ \\
\hline & 3 & $54.63 \pm 1.73$ & $0.37 \pm 1.71$ & $26.23 \pm 1.27$ & $0.04 \pm 0.08$ & $88.28 \pm 4.27$ & $26.8 \pm 1.09$ \\
\hline & 6 & $56.97 \pm 0.54$ & $1.07 \pm 0.96$ & $27.06 \pm 0.41$ & $0.04 \pm 0.04$ & $93.77 \pm 1.28$ & $27.24 \pm 0.38$ \\
\hline & 9 & $61.16 \pm 0.55$ & $4.17 \pm 1.06$ & $30.88 \pm 0.39$ & $0.13 \pm 0.03$ & $82.54 \pm 1.86$ & $31.31 \pm 0.49$ \\
\hline & 12 & $56.14 \pm 3.16$ & $11.91 \pm 1.56$ & $28.05 \pm 2.26$ & $0.49 \pm 0.1$ & $65.5 \pm 4.32$ & $31.12 \pm 1.76$ \\
\hline & 15 & $60.85 \pm 0.5$ & $11.24 \pm 1.53$ & $31.36 \pm 0.34$ & $0.36 \pm 0.05$ & $70.64 \pm 2.5$ & $33.58 \pm 0.6$ \\
\hline
\end{tabular}


Table S5:- Pulp and peel color indices of persimmon (Diospyros kaki cv. 'Naiyoushi') fruits during different ripening stages.

\begin{tabular}{|c|c|c|c|c|c|c|c|}
\hline Treatment & $\begin{array}{l}\text { Ripening } \\
\text { stages }\end{array}$ & $L^{*}$ & $a^{*}$ & $b^{*}$ & $a^{* / /} b^{*}$ & $\mathrm{H}^{o}$ & $\mathbf{C}^{*}$ \\
\hline \multicolumn{8}{|l|}{ Pulp } \\
\hline \multirow[t]{6}{*}{$\mathrm{H}_{2} \mathrm{O}$} & 0 & $66.82 \pm 0.67$ & $5.34 \pm 0.34$ & $31.24 \pm 0.29$ & $0.17 \pm 0.01$ & $80.31 \pm 0.61$ & $31.71 \pm 0.29$ \\
\hline & 3 & $66.24 \pm 0.72$ & $7.1 \pm 0.54$ & $32.28 \pm 0.22$ & $0.22 \pm 0.02$ & $77.65 \pm 0.91$ & $33.09 \pm 0.27$ \\
\hline & 6 & $67.2 \pm 0.52$ & $4.52 \pm 0.34$ & $32.44 \pm 0.16$ & $0.14 \pm 0.01$ & $82.1 \pm 0.58$ & $32.77 \pm 0.18$ \\
\hline & 9 & $66.82 \pm 0.77$ & $7.6 \pm 0.48$ & $32.52 \pm 0.21$ & $0.23 \pm 0.01$ & $76.9 \pm 0.76$ & $33.43 \pm 0.28$ \\
\hline & 12 & $66.26 \pm 0.75$ & $8.99 \pm 0.44$ & $32.81 \pm 0.2$ & $0.27 \pm 0.01$ & $74.69 \pm 0.73$ & $34.05 \pm 0.22$ \\
\hline & 15 & $65.08 \pm 0.72$ & $6.45 \pm 0.35$ & $32.5 \pm 0.34$ & $0.2 \pm 0.01$ & $78.77 \pm 0.62$ & $33.15 \pm 0.34$ \\
\hline \multirow[t]{6}{*}{$\mathrm{C}_{2} \mathrm{H}_{4}$} & 0 & $66.82 \pm 0.67$ & $5.34 \pm 0.34$ & $31.24 \pm 0.29$ & $0.17 \pm 0.01$ & $80.31 \pm 0.61$ & $31.71 \pm 0.29$ \\
\hline & 3 & $64.58 \pm 0.92$ & $8.87 \pm 0.34$ & $31.92 \pm 0.3$ & $0.28 \pm 0.01$ & $74.46 \pm 0.68$ & $33.15 \pm 0.22$ \\
\hline & 6 & $59.25 \pm 2.4$ & $6.59 \pm 0.34$ & $29.08 \pm 1.16$ & $0.23 \pm 0.02$ & $77.03 \pm 0.89$ & $29.85 \pm 1.12$ \\
\hline & 9 & $46.47 \pm 2.12$ & $10.99 \pm 0.52$ & $22.641 \pm 1.21$ & $0.49 \pm 0.02$ & $63.89 \pm 1.06$ & $25.2 \pm 1.24$ \\
\hline & 12 & $47.04 \pm 2.87$ & $10.46 \pm 0.3$ & $23.62 \pm 1.55$ & $0.46 \pm 0.02$ & $65.6 \pm 1.07$ & $25.87 \pm 1.51$ \\
\hline & 15 & $49.45 \pm 1.49$ & $11.88 \pm 0.95$ & $20.68 \pm 1.13$ & $0.57 \pm 0.03$ & $60.47 \pm 1.34$ & $23.9 \pm 1.38$ \\
\hline \multirow[t]{6}{*}{ SA } & 0 & $66.82 \pm 0.67$ & $5.34 \pm 0.34$ & $31.24 \pm 0.29$ & $0.17 \pm 0.01$ & $80.31 \pm 0.61$ & $31.71 \pm 0.29$ \\
\hline & 3 & $66.47 \pm 0.82$ & $6.61 \pm 0.54$ & $32.03 \pm 0.18$ & $0.21 \pm 0.02$ & $78.39 \pm 0.9$ & $32.74 \pm 0.24$ \\
\hline & 6 & $66.79 \pm 0.67$ & $4.17 \pm 0.43$ & $31.78 \pm 0.26$ & $0.13 \pm 0.01$ & $82.55 \pm 0.74$ & $32.08 \pm 0.28$ \\
\hline & 9 & $65.47 \pm 0.95$ & $8.45 \pm 0.55$ & $32.34 \pm 0.3$ & $0.26 \pm 0.02$ & $75.36 \pm 1$ & $33.47 \pm 0.23$ \\
\hline & 12 & $66.78 \pm 0.56$ & $8.12 \pm 0.37$ & $32.8 \pm 0.18$ & $0.25 \pm 0.01$ & $76.12 \pm 0.61$ & $33.81 \pm 0.19$ \\
\hline & 15 & $57.55 \pm 0.4$ & $9.53 \pm 1.12$ & $27.39 \pm 0.4$ & $0.35 \pm 0.04$ & $71.15 \pm 1.84$ & $29.14 \pm 0.7$ \\
\hline \multicolumn{8}{|l|}{ Peel } \\
\hline \multirow[t]{6}{*}{$\mathrm{H}_{2} \mathrm{O}$} & 0 & $54.26 \pm 0.47$ & $0.08 \pm 0.59$ & $24.56 \pm 0.31$ & $0.003 \pm 0.02$ & $89.84 \pm 1.34$ & $24.63 \pm 0.32$ \\
\hline & 3 & $53.97 \pm 0.31$ & $5.28 \pm 0.57$ & $25.23 \pm 0.23$ & $0.21 \pm 0.02$ & $78.29 \pm 1.24$ & $25.83 \pm 0.29$ \\
\hline & 6 & $54.38 \pm 0.35$ & $7.78 \pm 0.81$ & $25.26 \pm 0.27$ & $0.31 \pm 0.03$ & $73.07 \pm 1.65$ & $26.53 \pm 0.4$ \\
\hline & 9 & $54.11 \pm 0.57$ & $8.32 \pm 0.73$ & $25.12 \pm 0.41$ & $0.33 \pm 0.03$ & $71.73 \pm 1.58$ & $26.55 \pm 0.4$ \\
\hline & 12 & $55.71 \pm 0.37$ & $11.85 \pm 0.7$ & $25.89 \pm 0.32$ & $0.48 \pm 0.03$ & $65.54 \pm 1.25$ & $28.54 \pm 0.46$ \\
\hline & 15 & $58.21 \pm 0.55$ & $13.08 \pm 0.7$ & $27.53 \pm 0.4$ & $0.47 \pm 0.02$ & $64.7 \pm 1.08$ & $30.53 \pm 0.57$ \\
\hline \multirow[t]{6}{*}{$\mathrm{C}_{2} \mathrm{H}_{4}$} & 0 & $54.26 \pm 0.47$ & $0.08 \pm 0.59$ & $24.56 \pm 0.31$ & $0.003 \pm 0.02$ & $89.84 \pm 1.34$ & $24.63 \pm 0.32$ \\
\hline & 3 & $54.82 \pm 0.3$ & $11.51 \pm 0.86$ & $26.14 \pm 0.29$ & $0.44 \pm 0.03$ & $66.49 \pm 1.31$ & $28.63 \pm 0.61$ \\
\hline & 6 & $54.53 \pm 0.72$ & $9.89 \pm 1.05$ & $25.26 \pm 0.7$ & $0.39 \pm 0.04$ & $68.78 \pm 2.05$ & $27.29 \pm 0.79$ \\
\hline & 9 & $51.83 \pm 0.95$ & $16.97 \pm 0.53$ & $22.92 \pm 0.84$ & $0.75 \pm 0.04$ & $53.37 \pm 1.27$ & $28.58 \pm 0.77$ \\
\hline & 12 & $51.39 \pm 1.58$ & $16.39 \pm 0.68$ & $22.24 \pm 0.91$ & $0.75 \pm 0.06$ & $53.52 \pm 1.4$ & $27.7 \pm 0.9$ \\
\hline & 15 & $49.45 \pm 1.49$ & $11.88 \pm 0.95$ & $20.68 \pm 1.13$ & $0.57 \pm 0.03$ & $60.47 \pm 1.34$ & $23.9 \pm 1.38$ \\
\hline \multirow[t]{6}{*}{ SA } & 0 & $54.26 \pm 0.47$ & $0.08 \pm 0.59$ & $24.56 \pm 0.31$ & $0.003 \pm 0.02$ & $89.84 \pm 1.34$ & $24.63 \pm 0.32$ \\
\hline & 3 & $54.02 \pm 0.41$ & $5.16 \pm 1.09$ & $25.12 \pm 0.48$ & $0.2 \pm 0.04$ & $78.84 \pm 2.08$ & $25.8 \pm 0.69$ \\
\hline & 6 & $54.44 \pm 0.3$ & $3.49 \pm 0.8$ & $24.61 \pm 0.41$ & $0.19 \pm 0.03$ & $82.16 \pm 1.71$ & $24.96 \pm 0.5$ \\
\hline & 9 & $55.46 \pm 0.51$ & $10.94 \pm 1.05$ & $25.88 \pm 0.47$ & $0.42 \pm 0.04$ & $67.41 \pm 1.76$ & $28.22 \pm 0.75$ \\
\hline & 12 & $56.53 \pm 0.52$ & $11.31 \pm 0.87$ & $26.35 \pm 0.39$ & $0.43 \pm 0.03$ & $67.01 \pm 1.37$ & $28.74 \pm 0.66$ \\
\hline & 15 & $57.55 \pm 0.4$ & $9.53 \pm 1.12$ & $27.39 \pm 0.4$ & $0.35 \pm 0.04$ & $71.15 \pm 1.84$ & $29.14 \pm 0.7$ \\
\hline
\end{tabular}

\section{References:-}

1. Kim, T.C. and Ko, K.C. (1995): Classification of persimmon (Diospyros kaki Thunb.) cultivars on the basis of horticultural traits. Journal of the Korean Society for Horticultural Science 36: 331-342.

2. Celik, A. and Ercisli, S. (2007): Persimmon cv. Hachiya (Diospyros kaki Thunb.) fruit: Some physical, chemical and nutritional properties. International Journal of Food Sciences and Nutrition 18: 1-8. 
3. Del Bubba, M., Giordani, E., Pippucci, L., et al. (2009): Changes in tannins, ascorbic acid and sugar content in astringent persimmons during on-tree growth and ripening and in response to different postharvest treatments. Journal of Food Composition and Analysis 22(7-8): 668-677.

4. Ebert, G. and Gross, J. (1985): Carotenoid changes in the peel of ripening persimmon (Diospyros kaki) cv. Triumph. Phytochemistry 24 (1): 29-32.

5. Gorinstein, S., Zemser, M., Haruenkit, R., et al. (1999): Comparative content of total polyphenols and dietary fiber in tropical fruits and persimmon. Journal of Nutritional Biochemistry 10(6): 367-371.

6. Hongyan, G. (2006): Effects of ethylene on the flavor and aroma constituents biosynthesis in tomato fruit. Ph.D. Thesis, Chinese Agricultural University.

7. McGuire, R,G. (1992): Reporting of objective colour measurements. HortScience 27(12): 1254-1255.

8. Voss, D.H. (1992): Relating colourimeter measurement of plant colour to the Royal Horticultural Society colour chart. HortScience 27: 1256-1260.

9. Yonemori, K., Sugiura, A. and Yamada, M. (2000): Persimmon genetics and breeding. In: Janick J (ed). Plant Breeding Reviews 19: 191-225.

10. Li, M.J., Liang, D., Pu, F., et al. (2009): Ascorbate levels and the activity of key enzymes in ascorbate biosynthesis and recycling in the leaves of 22 Chinese persimmon cultivars. Scientia Horticulturae 120: 250256.

11. Zhao, D.Q., Zhou, C.H., Sheng, Y., et al. (2011): Molecular cloning and expression of phytoene synthase, lycopene beta-cyclase, and beta-carotene hydroxylase genes in persimmon (Diospyros kaki L.). Plant Molecular Biology Reporter 29(2): 345-351.

12. Wang, Y., Hossain, D., Perry, P.L., et al. (2012): Characterization of volatile and aroma-impact compounds in persimmon (Diospyros kaki L., var. Triumph) fruit by GC-MS and GC-O analyses. Flavour and Fragrance Journal 27(2): 141-148.

13. Candir, E.E., Ozdemir, A.E., Kaplankiran, M. and Toplu, C. (2009): Physicochemical changes during growth of persimmon fruits in the East Mediterranean climate region. Scientia Horticulturae 121(1): 42-48.

14. Celik, A. and Ercisli, S. (2008): Persimmon cv. Hachiya (Diospyros kaki Thunb.) fruit: some physical, chemical and nutrional properties. International Journal of Food Sciences and Nutrition 59(7-8): 599-606.

15. Zhao, S.Y., Guo, F.C. and Zhang, J.S. (2002). Study on technology of storage and fresh-keeping of 'Mopan' persimmon (in Chinese). Storage and process 1:18.

16. Besada, C., Sanchez, G., Salvador, A. and Granell, A. (2013): Volatile compounds associated to the loss of astringency in persimmon fruit revealed by untargeted GC-MS analysis. Metabolomics 9(1): 157-172.

17. Zhou, C.H., Sheng, Y., Zhao, D.Q., et al. (2010): Variation of oleanolic and ursolic acid in the fesh of persimmon fruit among different cultivars. Molecules 15: 6580-6587.

18. Xie, X.L., Yin, X.R. and Chen, K.S. (2016): Roles of APETALA2/Ethylene-Response Factors in regulation of fruit quality. Critical Reviews in Plant Sciences 35(2): 120-130.

19. Zhu, Y.M., Rudell, D.R., and Mattheis, J.P. (2008): Characterization of cultivar differences in alcohol acyltransferase and 1-aminocyclopropane-1-carboxylate synthase gene expression and volatile ester emission during apple fruit maturation and ripening. Postharvest Biology and Technology 49(3): 330-339. 
20. Itamura, H., Kitamura, T., Taira, S., et al. (1991): Relationship between fruit softening, ethylene production and respiration in Japanese persimmon 'Hiratanenashi'. Journal of the Japanese Society for Horticultural Science 60: 695-701.

21. Li, G., Jia, H., Li, J., et al. (2014): Emission of volatile esters and transcription of ethylene- and aroma-related genes during ripening of 'Pingxiangli' pear fruit (Pyrus ussuriensis Maxim). Scientia Horticulturae 170: 17-23.

22. Supapvanich, S. (2015): Effects of salicylic acid incorporated with lukewarm water dips on the quality and bioactive compounds of Rambutan fruit (Nephelium lappaceum L.). CMU Journal of Natural Science 14(1): 23-27.

23. Baninaiem, E., Mirzaaliandastjerdi, A.M., Rastegar, S. and Abbaszzade, K.H. (2016): Effect of pre- and postharvest salicylic acid treatment on quality characteristics of tomato during cold storage. Advances in Horticultural Science 30 (3): 183-192.

24. Babalar, M., Asghari, M., Talaei, A. and Khosroshahi, A. (2007): Effect of pre- and postharvest salicylic acid treatment on ethylene production, fungal decay and overall quality of Selva strawberry fruit. Food Chemistry 105(2): 449-453.

25. Aghdam, M.S., Motallebiazar, A., Mostofi, Y., et al. (2010): Effects of MeSA vapor treatment on the postharvest quality of Hayward kiwifruit. 6th International Postharvest Symposium, Antalya, Turkey, Acta Horticulurae 877: 743-748.

26. Thomas, P., Chen, T.S. (1998): Quantitative analyses of major carotenoid fatty acid esters in fruits by liquid chromatography: persimmon and papaya. Journal of Food Science 53(6): 1720-1722.

27. Nakagawa, T., Nakatsuka, A., Yano, K., et al. (2008): Expressed sequence tags from persimmon at different developmental stages. Plant Cell Reports 27(5): 931-938.

28. Robert, V., Jana, J., Maja, M.P., et al. (2010): Comparative study of primary and secondary metabolites in 11 cultivars of persimmon fruit (Diospyros kaki L.). Food Chemistry 119: 477-483.

29. Zhao, D.Q., Zhou, C.H., and Tao, J. (2011): Carotenoid accumulation and carotenogenic genes expression during two types of persimmon fruit (Diospyros kaki L.) development. Plant Molecular Biolology Reporter 29(3): 646-654.

30. Rodrigo, M.J., Marcos, J.F., and Zacarias, L. (2004): Biochemical and molecular analysis of carotenoid biosynthesis in flavedo of orange (Citrus sinensis L.) during fruit development and maturation. Journal of Agricultural and Food Chemistry 52(22): 6724-31.

31. Crisosto, C.H., Garner, D., Crisoto, G.M., et al. (1994): Late harvest and delayed cooling induce internal browning of 'Ya Li' and 'Seuri' Chinese pears. HortScience 29(6): 667-670.

32. Intelmann, D., Jaros, D., and Rohm, H. (2005). Identification of color optima of commercial tomato catsup. European Food Research and Technology 221: 662-666. 